\title{
Fuentes para el estudio de la ciudad medieval (siglos XIII-XV): tratados de gobierno. Definición de un género literario
}

\section{Sources for the study of medieval city ( $13^{\text {th }}$ to $15^{\text {th }}$ centuries $)$ : trea- tises of government. Definition of a literary genre}

\author{
Josué Villa Prieto \\ Università degli Studi di Roma "Tor Vergata" \\ josuevillaprieto@gmail.com
}

Recibido: 25/03/2014

Aceptado: 10/06/2014

\section{RESUMEN}

El objeto de este artículo es analizar las particularidades literarias de los tratados bajomedievales destinados a la formación de los regidores urbanos en la Baja Edad Media. Este tipo de tratados se desarrollan como género literario se durante los siglos XIII-XV; en su configuración intervienen tres elementos: las ordenanzas reales sobre el funcionamiento de las instituciones locales, los textos pedagógicos sobre materia política y moral de la Antigüedad Clásica y Tardía, y la tratadística coetánea europea, especialmente la elaborada en el humanismo italiano. La segunda parte del artículo se centra en exponer la influencia de los tratados italianos sobre los hispanos, con autores como Egidio Romano (De regimine principum), Leonardo Bruni (De nobiliate) o Bartolo de Sasoferrato (De insigniis et armis), entre otros. Por otra parte, los tratados peninsulares que permiten un mejor estudio de la caracterización ideal de la nobleza urbana con responsabilidades políticas son las obras de Ramón Llull, don Juan Manuel, Francesc Eiximenis, Juan de Alarcón, Alonso de Cartagena, Rodrigo Sánchez de Arévalo y Diego de Valera.

Palabras clave: Tratados de gobierno, ciudad medieval, regidores urbanos, educación y moralidad medieval, Rodrigo Sánchez de Arévalo, Diego de Valera.

\begin{abstract}
This article aims to expose the literary characteristics of the treatises used to provide professional training to urban councillors in the Late Middle Ages. Manuals for urban rulers as a literary genre were developed from the 13th to the 15th centuries and are composed of three basic elements: royal ordinances regarding the functioning of local institutions, educational texts on politics and morals from Classical and Late Antiquity, and European medieval treatises, especially those from Italian Humanism. The second part of this article focuses on the influence of Italian treatises on Spanish treatises, by authors such as Giles of Rome (De regimine principum), Leonardo Bruni (De nobiliate) or Bartolus de Saxoferrato (De insigniis et armis), among other writers. On the other hand, peninsular treatises which allow a better study of ideal characterization of urban nobility with political responsibilities are the treatises of Ramón Llull, Juan Manuel, Franscesc Eiximenis, Juan de Alarcón, Alonso de Cartagena, Rodrigo Sánchez de Arévalo and Diego de Valera.
\end{abstract}


Key words: Governing treatises, medieval city, urban rulers, education and morality, Rodrigo Sánchez de Arévalo, Diego de Valera.

Sumario: 1. Introducción. 2. Contexto político-cultural del auge de los tratados sobre el buen gobierno de la ciudad. 2.1. Ordenanzas reales. 2.2. Influencia de los tratados políticos de la Antigüedad y la tradición medieval. 3. Repertorio y posibilidades de los tratados bajomedievales. 3.1. La tratadística italiana. Egidio en la Península Ibérica. 3.2. Los tratados hispánicos: su caracterización. 4. El retrato ideal de la nobleza gubernamental: aspectos teóricos. 4.1. El espejo de regidor. 4.2. Las virtudes del consejero. 4.3. Caracterización básica del juez municipal. 5. En suma. 6. Apéndice: tratados para el estudio de la ciudad bajomedieval: una selección representativa. 7. Fuentes y bibliografía.

\section{INTRODUCCIÓN}

Stadtluft macht frei $i^{1}$. Durante las últimas dos décadas, las principales temáticas de los estudios sobre la ciudad medieval han sido la morfología y la interacción entre grupos sociales, siendo las fuentes más recurridas para ello las arqueológicas y diplomáticas $^{2}$. Sin embargo, aunque más modestas por su carácter teórico, las crónicas y los tratados también ofrecen muchas posibilidades para la investigación; si se procede a una lectura atenta y detenida es posible encontrar numerosos detalles sobre enclaves urbanos tanto de la Península Ibérica como del entorno mediterráneo. A modo de ejemplo, la Crónica de Pero Niño (1436) incluye descripciones detalladas de las poblaciones que visita Gutierre Díez de Games en sus viajes, como Londres, París, Túnez, Trípoli, Orán, Fez, Alejandría...; la Crónica de Morea de Juan Fernández de Heredia reseña las villas del Peloponeso a partir de las expediciones catalanas en la región durante el siglo XIV; o el Tratado de la perfección del triunfo militar de Alfonso de Palencia (1459) pormenoriza un periplo alegórico por las ciudades italianas. También los diarios de viajes contribuyen a conocer paisajes urbanos, como Il milione o el Libro del conoscimiento de todos los reinos (ambos del siglo XIII), Embajada a Tamerlán de Ruy González Clavijo (1406) o Andanças e viajes de Pedro Tafur

${ }^{1}$ Proverbio medieval alemán: El aire de la ciudad hace libre. El presente estudio cuenta con el apoyo de una ayuda postdoctoral Clarín-COFUND Marie Curie del Principado de Asturias y de la Comisión Europea. Este artículo presenta algunas conclusiones inéditas de mi tesis doctoral La educación nobiliaria en la tratadística bajomedieval castellana: aspectos teóricos (Oviedo, 2013), concretamente del capítulo quinto, destinado a las funciones sociales de la nobleza y a su compromiso gubernamental. Dicha tesis, dirigida por F.J. Fernández Conde bajo la tutoría de M.S. Beltrán Suárez, ha sido defendida en el Departamento de Historia de la Universidad de Oviedo el pasado 28 de noviembre de 2013, y ha contado con la ayuda de una beca predoctoral subvencionada por el Gobierno del Principado de Asturias con cargo a fondos provenientes del Plan de Ciencia, Tecnología e Innovación (PCTI) 2006-2009. Es de destacar la gran ayuda y los consejos brindados por la profesora M. Álvarez Fernández en la elaboración de los apartados dedicados al mundo urbano.

2 Vid. F.p. Iradiel Murugarren: "El mundo urbano: propuestas y perspectivas de la investigación medieval", Millars. Geografia-Historia, 13, 1990, 57-66. B. Arízaga Bolumburu valora las fuentes textuales que permiten el estudio de la morfología urbana en La imagen de la ciudad medieval. La recuperación del paisaje urbano, Santander, 2002.

${ }^{3}$ El texto recoge el viaje de varios embajadores de Enrique III a Samarcanda para ofrecer su amistad al sultán mongol; recorren el Mediterráneo hasta Constantinopla, Asia Menor, Anatolia y Persia. 
$(1453 \text { y } 1457)^{4}$. Mención aparte merece la colección de vistas panorámicas y planos integrados en el Civitatis Orbis terrarum (1570; ed. española 1588).

El objeto de este estudio no es la cronística sino otro género literario: los tratados destinados a la educación de los regidores urbanos ${ }^{5}$. Este tipo de composiciones prolifera en toda Europa durante los albores de la Modernidad, residiendo la base de su contenido en los doctrinales medievales de inspiración clásica y patrística que se presentan y analizan, mediante un método comparativo, a lo largo de nuestra exposición. En primer lugar se concreta los textos antiguos sobre el gobierno de la ciudad conocidos en la Baja Edad Media para, a continuación, examinar detalladamente la influencia de las doctrinas del humanismo italiano en el hispano. Finalmente, en la tercera parte, mucho más breve, se sintetizan algunas consideraciones sobre el ideal de nobleza urbana con competencias regidoras, consejeras y judiciales ${ }^{6}$.

\section{CONTEXTO POLÍTICO-CULTURAL DEL AUGE DE LOS TRATADOS SOBRE EL BUEN GOBIERNO DE LA CIUDAD}

El florecimiento de la tratadística relativa a temas urbanos está estrechamente relacionado con el proceso de desarrollo que experimentan las ciudades durante la Plena Edad Media. Desde el punto de vista de la gobernación, tema que centra nuestro interés, los núcleos del centro y norte de Italia transforman su modelo de comuna aristocrática por el de la podestà; ello significa la sustitución de un sistema rotatorio de familias aristocráticas por el gobierno personal de un extranjero que, elegido por la asamblea municipal como cabeza de la curia, pretende garantizar una labor incorruptible alejada de cualquier forma de connivencia directa en los entresijos de los intereses particulares. En Las Partidas leemos una definición de podestà’:

"Potestades llaman en Ytalia a los que escogen por regidores de las villas e de los grandes castillos, e estos an poder de juzgan segunt ley o fuero en aquellos lugares que son escogidos, en aquellas cosas e por tanto tiempo commo les fuere otorgado por los omnes daquel lugar, e non en mas".

Este sistema lo conocen centros como Padua, Pisa, Génova y Florencia en un tiempo marcado por el aumento demográfico y el inicio de programas de construcción

\footnotetext{
${ }^{4}$ El diario describe las experiencias del cordobés en Italia, Alemania, Polonia, Asia Menor, Oriente Medio y Egipto.

${ }^{5}$ Las ediciones consultadas de los tratados referidos se especifican en las indicaciones a pie de página. En cuanto a los manuscritos conservados en archivos y bibliotecas, no se explicitan al haber ya numerosos catálogos publicados sobre ello; vid. al respecto C. Alvar y J.m. Lucía Megías: Diccionario filológico de Literatura Medieval española. Textos y transmisión, Madrid, 2002.

${ }^{6}$ A lo largo del trabajo habrá ocasión de ofrecer detalles sobre la bibliografía dedicada a la tratadística gubernamental (A. López-Amo y Marín, F.E. Tejada, A. Martínez Casado, J.A. Maravall, L. Cervera Vera, V. Muñoz Delgado, S. Vila, A. Antelo Iglesias, M.I. Pérez de Tudela y Velasco, M. Haro Cortés, J.L. Martín, R. da Costa, D. Nogales Rincón, J.A. Solórzano Telechea, C. Mancineli, C. Vilanou Torrado...). A modo introductorio, vid. las monografías de J.M. CASTRO y CALVo: El arte de gobernar en las obras de don Juan Manuel, Barcelona 1945; y G. MuratoRE: La ciudad renacentista: tipos y modelos a través de los tratados, Madrid, 1980.

${ }^{7}$ Partida II, título I, ley 13.
} 
de obras públicas ${ }^{8}$. Con objeto de educar al podestà y a sus oficiales, un creciente número de consejeros, juristas y moralistas, tanto laicos como religiosos, escriben auténticos manuales sobre asesoría ministerial definiendo sus competencias y virtudes.

Durante toda la Baja Edad Media existe un continuo contagio de modas y costumbres entre la Península Itálica y la Ibérica motivado tanto por los intercambios comerciales como por los viajes de estudio que emprenden numerosos intelectuales para completar sus estudios universitarios e iniciar responsabilidades de representación política. Las temáticas de la tratadística italiana se trasladan así a la hispánica9 .

La administración local hispana recae en manos de los jurados, denominados así por jurar su cargo al ser designados entre los bono homines cada año, fruto de la elección del concejo, como representantes de sus intereses en la labor gubernamental ${ }^{10}$. Estos, junto a otros oficiales entre los que destaca el alcalde y el juez local, integran una asamblea vecinal o cabildo que también recibe el nombre de "consejo", "consell", "regimiento", "ayuntamiento"..., según el ámbito geográfico. Aunque los orígenes de esta institución se remontan a las cartas municipales del siglo XI, es Alfonso $\mathrm{X}(1252-1284)$ quien impulsa en las ciudades determinados instrumentos jurídicos en los que se especifica la asamblea de vecinos como organismo con capacidad suficiente para nombrar oficiales y tomar ciertas decisiones.

Esta situación de "concejo abierto" o concilium torna con Alfonso XI (1312-1350) a un "concejo cerrado" integrado por oligarcas municipales, impuestos directamente por la corona bajo el pretexto de defender la paz y el orden público. Es en 1345 cuando el monarca crea el regimiento en las cartas que concede a Burgos, León, Segovia y al año siguiente también a Madrid, atribuyéndole las funciones que hasta ahora correspondían al concejo; así, son los regidores quienes eligen a los magistrados municipales, siempre procurando garantizar los intereses regios. El hecho de que estos individuos concentren en su haber todo el poder político y económico de la comarca, y que conviertan el regimiento en una institución vitalicia incluso hereditaria, trae consigo gran malestar entre la burguesía y ciertos grupos nobiliarios enfrentados en-

${ }^{8}$ A modo de referencia básica, una aproximación al particularismo italiano en la Historia Urbana de la Edad Media Occidental en G. Cherubins: Le città europee del Medioevo, Milán, 2009 o (y más antiguo, Le città italiane dell'età di Dante, Pisa, 1991); o E. Crouzet-Pavan y E. Lecuppre-Desjardin (Coords.): Villes de Frandre et d'Italie (XIIIe-XVIe siècle). Les enseignements d'une comparaison, Turnhout, 2008. Sobre los modelos de república, vid. G. Pетті BALBI: Governare la città: pratiche sociali e linguaggi politici a Genova in età medievale, Firenze, 2007, dedicado a Génova; o el estudio también de E. Crouzet-Pavan sobre la dinámica social en Venecia y sus espacios Sopra le acque salse. Espaces, pouvoir et société à Venise à la fin du Moyen Age, 2 vols., Roma, 1992; esta también es objeto de análisis por parte de A. ZorZI en su amplísima bibliografía; vid., a modo de referencia, Una città, una Repubblica, un impero. Venezia (697-1797), Milán, 1994. Más antiguos pero igualmente interesantes para la comprensión del tema son los trabajos de E. Guidons: La città dal Medioevo al Rinascimento, Roma-Bari, 1992; M. GINATEMPO y L. SANDRI: L'Italia delle città: il popolamento urbano tra Medioevo e Rinascimento (secoli XIII-XVI), Florencia, 1990; N. GuglielmI: La ciudad medieval y sus gentes: Italia, siglos XII-XV, Buenos Aires, 1981; D. WALEY: Le città-repubblica dell'Italia medievale, Turín, 1980; y G. Fasoli Y F. BocchI: La città medievale italiana, Florencia, 1973.

${ }^{9}$ Sobre las relaciones personales entre los humanistas de ambas penínsulas a finales de la Edad Media vid. A. Gómez Moreno: España y la Italia de los humanistas. Primeros ecos, Madrid, 1994.

${ }^{10}$ Estos jurados poseen apelativos distintos en otros ámbitos geográficos: procuradores, regidores, corregidores, alcaldes, senadores, priores, potestades, cónsules, praetores, paciarii... Vid. Regiment de la cosa publica, p. 99 y s. El autor de este tratado es el catalán Francesc Eiximenis; luego habrá ocasión de estudiarlo con detenimiento. 
tre sí. Para solucionar las problemáticas derivadas se crea la figura del corregidor, autoridad con funciones inspectoras ante las denuncias y disturbios en el gobierno municipal que imparte justicia, igualmente, en nombre del rey.

El corregimiento también debe comprenderse como una medida encaminada a la centralización del poder monárquico en detrimento del nobiliario y de la independencia del patriciado urbano (caballeros o ciudadanos amparados en los fueros y privilegios privativos de las ciudades y contrarios a la nueva legislación general de los reinos desde finales del siglo XIII). Se crea en las cortes de León convocadas por Alfonso XI en 1349 aunque no se definen sus atribuciones judiciales hasta las de Toledo en 1480 durante el reinado de Isabel I. En este tiempo los corregidores se encargan de gestionar los recursos de la ciudad, de hacer frente a las necesidades de sus habitantes y de ejecutar órdenes reales como detenciones de delincuentes o publicaciones de informaciones. Así, por medio de su labor, la realeza interviene en el gobierno local frenando las aspiraciones hegemónicas de la aristocracia local y solucionando los conflictos derivados de la confluencia de poderes con intereses contrapuestos en un mismo espacio ${ }^{11}$.

El hecho de que los magistrados urbanos posean facultades administrativas, ejecutivas y judiciales capaces de determinar el ritmo social, económico y cultural de la ciudad impulsa a los intelectuales a componer tratados sobre las cualidades del buen político. En la configuración de este género literario intervienen tres elementos claramente diferenciados:

a. Las ordenanzas reales sobre el funcionamiento de las instituciones del gobierno local.

b. Los textos pedagógicos sobre materia política y moral de los autores antiguos, leídos y traducidos a finales de la Edad Media.

c. La tratadística coetánea europea, especialmente la elaborada en el humanismo italiano.

\subsection{ORDENANZAS REALES}

Las Partidas (1256-1265) es el primer texto jurídico que define la personalidad y los atributos de los gobernantes; el Rey Sabio expone en la primera de las siete que la con-

${ }^{11}$ Una visión de conjunto sobre el gobierno de las ciudades en las coronas de Castilla y de Aragón en M. Asenjo GonzÁlez: "La utopía política en el ámbito urbano", en M. Alvira Cabrer y J. Díaz IbáÑez (Coords.): Medievo utópico. Sueños, ideales y utopías en el imaginario medieval, Madrid, 2011, 141-154; o J. CERDÁ RuIz-FunEs: "Jurados, iurats, en municipios españoles de la Baja Edad Media (reflexiones para una comparación)", Historia, instituciones, documentos, 14, 1987, 27-39. Sobre el caso castellano podemos destacar varios estudios clásicos como los de B. GonzÁlez Alonso: El corregidor castellano (1348-1808), Madrid, 1970; y A. Bermúdez Aznar: El corregidor en Castilla durante la Baja Edad Media, Madrid, 1970, cuyo contenido lo sintetiza en "El asistente real en los concejos castellanos medievales", en VV.AA.: Actas del II Symposium de Historia de la Administración, Madrid, 1971, 223-251; M. Lunenfeld: Los corregidores de Isabel la Católica, Barcelona, 1989; o E. Mitré: La extensión del régimen de corregidores en el reinado de Enrique III de Castilla, Valladolid, 1969. No hemos podido consultar, en cambio, el estudio de N. Guglielmi: "Los alcaldes reales en los concejos castellanos", Anales de Historia Antigua y Medieval, 7, 1956, 79-109. También destaca la monografía de F. ALBI: El corregidor en el municipio español bajo la Monarquía absoluta, Madrid, 1943. 
forman las aptitudes que debe poseer tanto desde una óptica técnica como devota (título I). En las restantes también incluye algunas consideraciones aunque de manera más dispersa; así, en la Segunda insiste en la conveniencia de la devoción espiritual (título II), de unos valores éticos acordes a la moral cristiana (títulos IV y V), de apreciar el significado de la justicia (título IX) y de defender los intereses de los ciudadanos por encima de los personales (título X); igualmente, la Tercera retrata los cánones ideales de los jueces y abogados (títulos IV-VIII), y de sus asesores (título XXI) ${ }^{12}$. La materia concerniente a la justicia se concreta con mucha más precisión en el Ordenamiento de Alcalá (1348), aprobado un año antes de las cortes de León que diseñan el corregimiento a las que antes aludimos. La única referencia sobre el gobierno urbano explicita, simplemente, la obligación de los vasallos de obedecer a los oficiales del rey en sus señoríos, villas y ciudades (título XX, leyes 1 y 8), no definiendo sus atribuciones en ninguna otra parte del texto, ni siquiera en el epílogo que recoge las disposiciones de las cortes de Alfonso VII en Nájera (1138) a las que el Onceno otorga validez.

Las leyes sobre política urbana que firman los reyes bajomedievales ratifican estos ordenamientos sin apenas modificaciones. Muestra de ello son las que expide Juan II de Castilla entre 1434 y 1436 como respuesta a las denuncias interpuestas por las ciudades ante la inobservancia de la legalidad en sus cargos. El monarca obliga a todos sus oficiales a jurar debidamente sus cometidos y a cumplir las responsabilidades adyacentes bajo pena de multa y suspensión de cargos. Estas normas están transcritas en los cuadernos de cortes y en las diferentes crónicas del periodo, la de Fernán Pérez de Guzmán (1378-1460) y Pero Carrillo de Huete (1380-1448). El primero, Señor de Batres, es sobrino del Canciller Mayor Pero López de Ayala, a quien sustituye como cronista oficial ${ }^{13}$; el segundo, por su parte, es el jefe de los halconeros de la casa real, de ahí su sobrenombre el Halconero, y compositor de una historia mucho más personal e íntima que la anterior ${ }^{14}$.

12 No señalamos todos los títulos referentes a la ciudad medieval en Las Partidas sino sólo aquellos relativos al gobierno urbano. Se deja de lado, por tanto, temas como el urbanismo, las actividades económicas o los grupos sociales que cohabitan intramuros; sobre las posibilidades que ofrece el texto alfonsí para el estudio de estas cuestiones vid. los estudios de J.A. Bonachía Hernando: "La ciudad en Las Partidas: edificaciones y apostura urbana”, en M.c. Ribeiro y A. Sousa Melo (Coords.): Evoluçâo da paisagem urbana. Transformaçâo morfológica dos tecidos históricos, Braga, 2013, 91-117; “Obras públicas, fiscalidad y bien común en las ciudades de la Castilla bajomedieval”, en J.M. Monsalvo AnTón (Coord.): Sociedades urbanas y culturas políticas en la Baja Edad Media castellana, Salamanca, 2013, 17-48; y "La imagen de la ciudad en Las Partidas: edificación, seguridad y salubridad urbanas”, Cuadernos de Historia de España, 85-86, 2011-2012, 115-134. También destacan los de F. Ruiz Gómez: "La ciudad en la obra jurídica alfonsí: el paisaje urbano y los grupos de poder”, en M. GonzÁlez Jiménez (Coord.): El mundo urbano en la Castilla del siglo XIII, I, Sevilla, 2006, 101-121; M.I. Pérez De Tudela y Velasco: "Ideario político y orden social en Las Partidas de Alfonso X”, En la España medieval, 13, 1991, 183-200; M.c. Cayetano Martín: "La ciudad medieval y el Derecho: el urbanismo en Las Partidas", Anales de Historia del Arte, 4, 1993-1994, 65-70; y A. Martínez CASAdo: "Los oficiales públicos de Las Partidas a los Reyes Católicos", en VV.AA.: Actas del II Symposium de Historia de la Administración, Madrid, 1971, 121-137.

13 Recientemente se ha publicado un estudio sobre las instituciones en época de Juan II, F. DE PAULA CAÑas GÁlvez: Burocracia y cancillería en la corte de Juan II de Castilla (1406-1454). Estudio institucional y prosopográfico, Salamanca, 2012; las labores oficiales y personales del canciller en pp. 39 y ss.

14 Vid. Crónica de Juan II de Fernán Pérez de Guzmán (ed. C. Rosell: Crónicas de los Reyes de Castilla, II, B.A.E., tomo LXVIII, Madrid, 1953, 273-695), pp. 529 y ss.; y Crónica del Halconero (J. De MatA CARRIAZO y ArroQuia, Madrid, 1946), pp. 236 y ss. 
Si leemos las disposiciones legislativas podemos comprobar cómo Juan II recurre al corregimiento para solucionar los males ocasionados por las luchas entre poderes enfrentados en las ciudades; ordena a sus representantes en las localidades que actúen de manera rigurosamente legítima y, ante las protestas ciudadanas, elaborar un informe para las cortes en el que se especifiquen sus causas ${ }^{15}$ :

"Que por quanto en las cibdades é villas de sus Reynos habia muchos vandos, por los quales se siguian muchas muertes de hombres, é robos é quemas é otros grandes maleficios, de lo qual se siguia daño en todos sus Reynos, é por esta causa muchas veces él embiaba sus Corregidores, los mas de los quales usaban de tal manera en los Corregimientos, que dexaban en los lugares mayor division que quando á ellos venian; é que por esto el Rey mandaba que todos los Corregidores que él embiase á qualesquier villas ó lugares de sus Reynos, fuesen tenidos de hacer verdadera relación a Su Merced de quien $o ́$ quales personas eran los que revolvian los tales vandos. E habida esta relacion por el Rey, luego los mandase venir á su Corte personalmente, dándoles Jueces que los oyesen, é mandando á su Fiscal que los acusase; lo qual así se puso en obra, é se guardó algun tiempo, é fue hecha justicia de algunos, é otros fueron desterrados por ciertos tiempos, segun la culpa en que los hallaron".

El rey también reglamenta las funciones de los oficios políticos urbanos, definiéndolos en los siguientes términos:

"Que el Corregidor sea tal qual cumpla al mi servicio é á esecucion de la mi justicia, proveyendo el oficio mas que á la persona, é que jure que no dió ni prometió, ni dará ni prometerá cosa alguna por esta razon, ni dara cosa ni parte de lo que rentare el oficio á persona alguna, so pena de perjuro é de infame, é de haber perdido el oficio á persona alguna, so pena de perjuro é de infame é de haber perdido el oficio, é nunca poder haber otro, é que este juramento haga en la ciudad, ó villa, ó lugar de que lo que yo proveyere de tal Corregimiento por ante Escribano público; é eso mesmo se haga é guarde en las Alcaldías é otros oficios de justicias é Alguacilazgos é Merindades de yo he de proveer".

"Que no se libren ni pasen renunciaciones de Alcaldías, ni Regimientos ni Alguacilazgos, ni Merindades, ni Juraderías, ni Escribanías, salvo de padre á hijo; y esto quando á mi pluguiere de proveer de qualquier de los dichos oficios al tal hijo de aquel que lo renunciare, él leyendo idoneo para ello, é no pasando ni excediendo al número antiguo".

"Que ningun Regidor no viva con Caballeros de la ciudad, ó villa, ó lugar donde él fuere Regidor".

"Que los Alcaldes, é Alguaciles, é Regidores ni el Mayordomo ni Escribanos de Concejo, ni otro por ellos, por sí ni por interpósita persona no puedan arrendar ni arrienden las rentas é propios de las cibdades é villas é lugares donde fueren oficiales, ni hayan parte en ellas, ni puedan ser fiadores ni aseguradores de los que las arrendaren".

En cuanto la imprecisión legal sobre el número de regidores que deben cohabitar en los consistorios, Juan II ordena en 1436:

"Que los mis oficios de Regimientos cada que vacaren por renunciacion $o ́$ muerte, $o ́$ en otra qualquier manera, se consuman en aquellos por quien vacaren hasta ser

${ }^{15}$ Crónica de Juan II, pp. 516 y ss. Las próximas citas textuales no especificadas siguen esta referencia. 
reducidos al número que eran al tiempo quel Rey Don Enrique mi padre é mi Señor, que Dios dé santo paraíso, pasó desta presente vida. E los que fueron proveidos de qualquier oficios de Regimientos, ó Alcaldías, ó Merindades, ó Alguacilazgos no sean rescebidos á los oficios hasta que juren en forma debida en el Consejo de la ciudad ó villa ó lugar donde fuere proveido de tal oficio por ante Escribano público, é que no dieren ni prometieren, ni darán ni prometerán por esto cosa alguna”.

Esta cifra varía según la ciudad y la época al no existir una norma expresa en los ordenamientos anteriores. A modo de referencia, por ejemplo, en Sevilla se dictamina el proceso de elección en 1254: cada 24 de junio, día de San Juan Bautista, se convocan votaciones para elegir a dos caballeros, dos ciudadanos y dos menestrales con objeto de que cada uno de ellos represente los intereses de cada estado. Por su parte, en Murcia son elegidos directamente por la corona desde 1337 para que non acaesca discordias ni departamento alguno; un siglo después, la cifra de jurados aumenta considerablemente, habiendo en 1424 un total de veintidós repartidos entre las once parroquias urbanas ${ }^{16}$.

Finalmente, junto a los regidores y corregidores se hallan los jueces y alcaldes, que con la ayuda de los jurados velan por el cumplimiento de las normativas áulicas. Se espera de ellos que tengan cargo de inquirir contra los transgresores de las Ordenanzas y que guarden las leyes de las Cortes de Alcalá hechas por el Rey Don Alonso, é confirmadas por mi -habla Juan II refiriéndose al Fuero Real y Las Partidas-en el Ayuntamiento de Segovia.

\subsection{INFLUENCIA DE LOS TRATADOS POLÍTICOS DE LA ANTIGÜEDAD Y LA TRADICIÓN MEDIEVAL}

Nuestros autores no sólo transcriben las normativas reales en sus obras políticas sino que, para dotarlas de argumentos, acuden a la Biblia, a los clásicos y a los Padres de la Iglesia. De la larga lista de escritores citados, el que mayor número de alusiones suma es Aristóteles; su obra es traducida al romance desde el siglo XIII y durante toda la Baja Edad Media, siendo la Politica la clave teórica de la doctrina sobre los modelos de gobierno (tiranía, oligarquía y democracia) y las virtudes elementales del gobernante ideal (libro VI). En el siglo XV destaca la famosa polémica entre Alonso de Cartagena y Leonardo Bruni sobre el modo de trasladar al romance las Ethicae.

Los autores más leídos después de Aristóteles son, a juzgar por el número de referencias textuales, Valero Máximo, Séneca, Cicerón, San Ambrosio, San Agustín y San Gregorio Magno. Todos ellos insisten en la dimensión moral de la educación política, siendo el más influyente de todos el Obispo de Hipona. En su De civitate Dei contrapone dos modelos de gobierno diferentes, el de la ciudad terrena, gobernada por las leyes humanas (representada alegóricamente por Babilonia), y el de la ciudad de Dios, regentada a través de las instrucciones bíblicas y de los sabios (Jerusalén); en la primera reina el caos y la desolación mientras que en la segunda triunfa el orden y la felicidad de los ciudadanos.

16 J. Cerdá Ruiz-Funes: “Jurados, iurats...”, pp. 29-38. 
Otros autores grecolatinos, tardoantiguos y patrísticos presentes en los tratados analizados son Homero, Hipodamo, Sócrates, Platón, Terencio, Catón, Varrón, Tito Livio, Ovidio, Horacio, Lucano, Flavio Josefo, Suetonio, San Buenaventura, Juan Crisóstomo, Petronio, Vegecio, Solino, Claudio Claudiano, Casiano, Boecio, Eusebio de Cesarea, San Isidoro, San Bernardo... ${ }^{17}$ Cada uno de ellos centra su discurso en materias muy concretas, de modo que los tratadistas bajomedievales aplican sus doctrinas a la intencionalidad de sus propias enseñanzas; así, De consolatione Philosophiae de Boecio refleja la integridad cristiana ante la adversidad que debe caracterizar al buen político, De re militari de Vegecio permite concretar la defensa de la ciudad en caso de ser atacada, o los Dicta de Catón recoge algunos consejos en forma de dichos sapienciales de interés (abstente de actividades públicas; teme a los magistrados $)^{18}$.

Otro tipo de composiciones que influye decisivamente en nuestros tratados es la cuentística sapiencial y proverbial de tradición oriental traducida al castellano durante el siglo XIII. Calila é Dymna es una narración de origen hindú (siglo IV a.C.) transcrita del original sánscrito -Panchatantra- al árabe -Kalila wa-Dymna-, y de esta lengua al romance en 1251 por Alfonso X con objeto de disponer de un modelo para la composición de cuentos ejemplares ${ }^{19}$. Las moralejas que incluye tratan todo tipo de temáticas, en su mayoría ligadas a la moralidad individual y a cuestiones ministeriales. De la misma fecha data Barlaam e Josafat, una leyenda sobre la educación de un príncipe abandonado por su padre cuya edición castellana adapta el texto original a los mensajes dogmáticos de la fe cristiana ${ }^{20}$.

Otro título a señalar es el Sendebar, traducido como el Libro de los engaños e los asayamientos de las mujeres (1253) bajo el encargo del infante don Fadrique, hijo de Fernando III; se trata de un conjunto de cuentos breves sobre los tormentos del hijo de un rey apresado injustamente por su malvada madrastra ${ }^{21}$. Por su parte, en $L a$ doncella Teodor, historia integrada en Mil y una noches, la protagonista es una mujer con gran prudencia y sabiduría que, comprada como esclava por un mercader, consigue salvar a su propietario de un sinfín de situaciones problemáticas ${ }^{22}$. Más ejemplos de libros de sabiduría son Bonium o Bocados de oro, una narración sobre un viaje espiritual a la India ${ }^{23}$; Poridad de poridades, versión de un texto original del siglo

17 Esta relación de nombres puede contrastarse en los pasajes de Egidio Romano y Rodrigo Sánchez de Arévalo sobre las cualidades del consejero; vid. al respecto la Glosa castellana a "De regimine principum" (Ed. J. Beneyto Pérez, Madrid, 2005), p. 847; y Suma de la politica (M. PENNA: Prosistas castellanos del siglo XV, I, B.A.E., tomo CXVI, Madrid, 1959, 249-309), pp. 288-291.

${ }^{18}$ Dicta Cathonis (Ed. Valencia, 1999), prólogo 5 (Foro parce) y 11 (Magistratum metue); vid. la edición castellana, empleada como instrumento para lecciones gramaticales y morales, en C. CLAVERÍA "La traslaçion del muy excelente doctor Caton llamado, hecha por un egregio maestro, Martín García llamado", Cuadernos de Estudios Caspolinos, 15, 1989, 29-140.

19 Vid. ed. P. De Gayangos: Escritores en prosa anteriores al siglo XV, B.A.E., tomo LI, Madrid, 1860, $1-78$.

20 Vid. ed. S. Carnero Burgos: Edición y estudio del Barlán y Josafat, 2 vols., Madrid, 1990.

21 Vid. ed. V. Orazi: Sendebar: Libro de los engaños de las mujeres, Barcelona, 2006.

22 Vid. ed. N. Baranda: Narrativa popular de la Edad Media: Doncella Teodor; Flores y Blancaflor; Paris y Viana, Madrid, 1995, 59-83.

23 Vid. ed. M. Crombach: Bonium, Bonn, 1971. 
IX de Yahya ibn al-Batrk que recoge enseñanzas generales de Aristóteles a Alejandro Magno ${ }^{24}$; el Libro de los doce sabios (De la nobleza y lealtad) ${ }^{25}$; y Flores de Filosofia, inspirada en el Libro de los cien capitulos ${ }^{26}$.

Estos relatos ejercen su influencia como modelo para la creación literaria durante la segunda mitad del siglo XIII debido al éxito que conocen las labores de traducción en las cortes de Alfonso X y Sancho IV. Igualmente, la materia abordada, muy amplia y heterogénea (la vida en la corte, los cometidos del gobernante, el significado de regir sobre los súbditos...), es adaptada a los planteamientos de la ética cristiana en sus versiones al castellano. Ambas características pueden comprobarse en obras como las de don Juan Manuel, cuyo estilo imita Calila é Dymna y Barlaam e Josafat, la Disciplina clericalis de Pedro Alfonso de Huesca o el Libre de saviesa atribuido a Jaime I. Más abajo se ampliarán detalles al respecto ${ }^{27}$.

Desde principios del siglo XIV y a lo largo de todo el periodo secular, la influencia de la tradición oriental en los specula peninsulares mengua y acrecienta la del occidente europeo, especialmente italiana. De modo similar, los autores, en sus labores de erudición, optan cada vez más por recurrir directamente a los textos clásicos en vez de a otro tipo de fuentes para buscar en ellas doctrinas y ejemplos de conductas. Ello es indicio de la génesis del humanismo en la Península Ibérica.

\section{REPERTORIO Y POSIBILIDADES DE LOS TRATADOS BAJOMEDIEVALES}

A continuación se ofrece un breve catálogo de los autores que escriben sobre el gobierno ideal de la ciudad. Para ello se resume, en primer lugar, el alcance de las composiciones europeas en suelo hispano prestando especial interés a la obra de Brunetto Latini, Egidio Romano, Leonardo Bruni y Bartolo de Sassoferrato por ser los más conocidos y difundidos gracias a traductores y glosadores que sintetizan sus escritos. Seguidamente se repasarán las particularidades definitorias de la tratadística gubernamental ibérica para dejar paso, en el siguiente apartado, a la caracterización arquetípica de los regidores, consejeros y jueces en el pensamiento bajomedieval.

24 Vid. ed. H.O. Bizzarri: Secreto de los secretos. Poridat de las poridades: Versiones castellanas del Pseudo-Aristóteles Secretum Secretorum, Valencia, 2011.

${ }^{25}$ Vid. ed. J. WALsh: "El Libro de los doce sabios o Tratado de la nobleza y lealtad (ca. 1237). Estudio y edición”, Boletín Oficial de la Real Academia Española (anejo), 29, 1925, Madrid.

26 Vid. ed. H. Knust: Dos obras didácticas y dos leyendas sacadas de manuscritos de la biblioteca del Escorial, Madrid, 1878, 3-83.

27 D. Nogales Rincón pone de relieve la importancia de este tipo de composiciones como fuente para las obras pedagógicas destinadas a reyes y nobles en su artículo "Los espejos de príncipes en Castilla (siglos XIII-XV): un modelo literario de la realeza bajomedieval”, Medievalismo. Boletín de la Sociedad Española de Estudios Medievales, 16, 2006, 9-39; el autor completa así las conclusiones de H.O. BizzArRI: "Las colecciones sapienciales castellanas en el proceso de reafirmación del poder monárquico (siglos XIII y XIV)", Cahiers de linguistique hispanique médiévale, 20, 1995, 35-73. Por otro lado, para una caracterización de las formas literarias vid. los libros de M. HARO CORTÉs: Los compendios de castigos del siglo XIII: técnicas narrativas y contenido ético, Valencia, 1995; y La imagen del poder real a través de los compendios del siglo XIII, Londres, 1996. 


\subsection{LA TRATADÍSTICA ITALIANA. EGIDIO EN LA PENÍNSULA IBÉRICA}

Como ya se ha explicado, los juristas italianos son los primeros en componer trataditos educativos para aleccionar y asesorar a los líderes políticos de sus ciudades. Entre otros conocen gran repercusión Guido Fava, Giovanni da Viterbo, Orfino da Lodi, Albertano de Brescia, Brunetto Latini, Egidio Romano, Marsilio de Padua, Bartolo de Sassoferrato, Coluccio Salutati, Leonardo Bruni, Lorenzo Valla o Maquiavelo. A continuación se repasa, de manera sintética, las razones de su importancia en la Literatura sobre el pensamiento político urbano.

Entre los precursores del género se encuentra el notario de Bolonia y profesor de Retórica Guido Fava (ca. 1190-1248); ciertamente no expone cuestiones relativas la jefatura urbana en su obra más famosa, Summa de vitiis et virtutibus (ca. 1220) ${ }^{28}$, pero sí que explica en ella las bases del ars dictaminis que los autores posteriores van a incorporar en sus programas pedagógicos; si tenemos, pues, en consideración esta obra, encontramos en la Oratoria y en la creación de discursos la primera lección para regidores de la tratadística italiana. Coetánea a esta composición data la anónima Oculus pastoralis (ca. 1222), un breve compendio de normas sobre el proceso de ascenso político del podestà y sus funciones ministeriales ${ }^{29}$; pese a su interés no conoce una gran difusión al no publicarse hasta cinco siglos después.

Durante la primera mitad del siglo XIII vive también Giovanni da Viterbo, asesor del podestá de Florencia, destinatario de su Liber de regimine civitatum $^{30}$; no existe acuerdo entre los especialistas sobre el momento de su redacción, de hecho se han propuesto fechas que oscilan entre 1238 y 1253 . El autor trata los mismos temas presentes en el Oculus pastoralis y añade otros dos que se convierten en recurrentes desde este momento: las relaciones políticas entre delegados imperiales y papales en las ciudades, y los distintos modos de administrar el territorio (justicia y finanzas) en tiempos de paz o de guerra. En cuanto a su innegable formación intelectual, muestra un gran conocimiento de los clásicos, especialmente de Séneca y Cicerón, sus principales fuentes junto al Corpus iuris civilis.

Coetáneo a Viterbo es Orfino da Lodi (ca. 1190-1252), autor de un pequeño manual dedicado a su hijo Marco que recoge sus experiencias como juez en diversas ciudades del centro y norte de Italia: De sapientia potestatis $(1245)^{31}$. En el momento de su elaboración trabaja al servicio de Federico de Antioquía, hijo ilegítimo del emperador Federico II y su embajador en la región.

El Liber consolationis et consilii (1246) de Albertano de Brescia (ca. 1195-1251), asesor del podestá de Génova, se divulga con mucho más éxito en la Península Ibérica gracias a la traducción que lleva a cabo Pero Gómez Barroso (ca. 1270-1345)

${ }^{28}$ Vid. ed. V. PINI: "Summa de vitiis et virtutibus", Quadrivium, 1, 1956, 41-152.

${ }^{29}$ Vid. D. Quaglioni: "La civitas medievale e le sue magistrature. L'Oculus pastoralis (1222)", Pensiero politico, 40 (2), 2007, 232-241. Consúltese ed. de D. Franceschi: Memoria dell'Academia delle Scienze di Torino. Classe di scienze morali, storiche e filologiche, 4 (11), 1966, 1-74.

${ }^{30}$ Vid. ed. C. SALVemini: Liber de regimine civitatum, Bolonia, 1901, 215-280.

31 Vid. ed. S. Pozzi: De sapientia potestatis, Lodi, 1998. 
bajo el título Libro del consejo e de los consejeros (1293) ${ }^{32}$. Este autor, supervisor de jueces, se forma intelectualmente en las casas de Pero López de Ayala y del Arzobispo de Toledo Gonzalo Gudiel, futuro Obispo de Cartagena y cardenal de Santa Práxede, donde conoce numerosos amigos a los que aconseja, a través de su obra, sobre el concepto de justicia pública y las formas de solucionar problemas derivados de este ejercicio.

Mayor impacto aún que el del Liber consolationis conoce el Libre dou tresor de

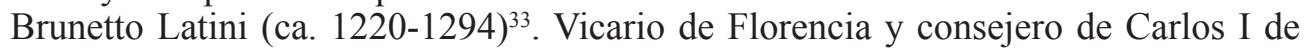
Nápoles, goza de gran prestigio en vida gracias a sus lecciones como profesor de Retórica y Oratoria, dos materias que considera fundamentales en la formación del político ${ }^{34}$; Dante, su discípulo más famoso, le dedica los versos del canto decimoquinto de su Divina comedia (séptimo círculo) alabándolo como sabio y gran consejero. Entre 1260 y 1267 elabora para el monarca napolitano el Libre dou tresor, una magna enciclopedia que pretende hacer acopio de los conocimientos universales; de los tres libros que lo integran, el tercero versa sobre el buen regimiento a partir de las obras de Cicerón y en especial Aristóteles. Es tal la importancia que Brunetto confiere a la política que la define como el governamiento de las çibdades, que es la mas noble et más alta sçiençia et el más noble ofiçio que sea en tierra ${ }^{35}$, una afirmación que le enfrenta a los coetáneos que subrayan la supremacía de la Teología sobre cualquier otra ciencia. A finales de la centuria, Sancho IV encarga su traducción del francés al castellano junto al Lucidario de Honorio de Autum, popularizándose así su lectura en la corte y convirtiéndose en un modelo literario para los specula principum ${ }^{36}$.

De todo el conjunto italiano, ninguna obra conoce mayor éxito y difusión en la Península Ibérica que la de Egidio Romano, también denominado comúnmente en los documentos de época Egidio Colonna o Gil de Roma (1243-1316). De regimine principum $(1280)^{37}$ es un tratado didáctico dedicado a Felipe IV de Francia inspirado en un ensayo homónimo que su maestro Santo Tomás de Aquino escribe para Hugo II de Chipre $(1265)^{38}$. Se compone de tres libros dedicados, respectivamente, a la

32 Vid. eds. VV.AA.: Albertani Brixiensis: Liber consolationis et consilii, Londres, 2009; y A. REy: Maestre Pedro: Libro del consejo e de los consejeros, Zaragoza, 1962.

33 Vid. ed. J. TurRó: Li libres dou tresor. Español-francés, Barcelona, 2010.

${ }^{34}$ La Retórica como materia fundamental en la educación del gobernante en F. ANDREws: “Albertano of Brescia, Rolandino of Padua and the rhetoric of legitimation", en J. EscalonA et alii (Coords.): Building legitimacy: political discourses and forms of legitimacy in medieval societies, Leiden, 2004, 319-340.

35 Libro del tesoro, III, 73, 1.

36 Sobre la fortuna de Brunetto Latini en Castilla y Aragón vid., respectivamente, los artículos de A.M. MonTero: "La castellanización de Li libres dou tresor de Brunetto Latino en la corte de Sancho IV (12841295): algunas notas sobre la recepción de la ética aristotélica", Anuario de estudios medievales, 40 (2), 2010 , 937-954; y C.J. WitTLin: "Les traduccions catalanes medievals del Tresor de Brunetto Latini", en I. MAFFIA SCARIATI (Coord.): Indagini sulla ricezione di Brunetto Latini dal Medioevo al Rinascimento, Firenze, 2008, 167-176. Una valoración general en F. López EstradA: "Sobre la difusión del Tesoro de Brunetto Latini en España”, Gesammelte Aufsätze zur Kulturgeschichte Spaniens, 16, 1960, 137-152.

37 Vid. ed. J. Beneyto PÉREz: Del regimiento de los príncipes y señores que han de regir a los otros (Glosa a "De regimine principum" de Egidio Romano), Madrid, 2005. Un estudio clásico para la comprensión de su obra en N. Mattioli: Studio critico sopra Egidio Romano Colonna, Roma, 1896.

${ }^{38}$ El tratado de Santo Tomás también es traducido y leído en España, siendo una de las piezas literarias que encarga Fernando el Católico para su propia educación; vid. D. Nogales Rincón: "En torno a la sabiduría 
exposición de las virtudes morales que deben poseer los príncipes (Del governamiento del mundo), a las relaciones conyugales-parentales en el ámbito privado (Del governamiento de la casa), y a las tareas de gobierno y defensa del territorio (Del governamiento de la ciudad e del reyno), siendo este último el de mayor interés por caracterizar los ideales de regidor, consejero, juez y capitán ${ }^{39}$. Aristóteles es la fuente primordial empleada por Egidio ${ }^{40}$, seguido de la Biblia y Santo Tomás, así como otros autores clásicos, patrísticos y escolásticos como Sócrates, Cicerón, Valerio Máximo, Séneca, Boecio, Justino, Macrobio, San Agustín, San Isidoro, San Jerónimo, San Anselmo, San Gregorio, Graciano y Pedro Lombardo.

El speculum del colonnesi se difunde rápidamente en toda Europa occidental, siendo la primera obra castellana que muestra su influencia Castigos y documentos de Sancho IV ${ }^{41}$. Su estructura es diferente al componerse de un solo libro dividido en noventa capítulos, pero el grueso de su contenido es una transcripción literal; los temas sobre gobierno y sociedad urbana se desarrollan sintéticamente en los capítulos XIII-XVII y LXII-LXVI. Sólo un ejemplo de los muchos posibles: la obra del Rey Bravo sigue exactamente De regimine principum al exponer las fuentes para el estudio de las pasiones y virtudes humanas, habiendo similitud plena entre ambas composiciones, incluso hasta en los signos de puntuación ${ }^{42}$ :

en el Cuatrocientos castellano: el prólogo a la traducción castellana del De regno ad regem Cypri de Tomás de Aquino dirigida a Fernando el Católico", Memorabilia, 12, 2009-2010.

39 Más abajo se ofrecerá una relación detallada de los temas que trata así como un cuadro comparativo confrontando las equivalencias de De regimine principum con otras obras a las que influye.

40 Vid. F.J. López De Goicoechea Zabala: "La glosa castellana al De Regimine Principum (1280) de Egidio Romano. La reducción aristotélica", Saberes. Revista de estudios jurídicos, económicos y sociales, 1 , 2003, disponible On-line en <http://www.uax.es/publicaciones/archivos/SABFUN03_007.pdf $>$ [con acceso el 2-II-2010].

${ }^{41}$ Vid. R. Beltrán: "El valor del consejo en los Castigos e documentos del rey don Sancho", en C. Alvar y J.M. Lucía Megías (Coords.): La Literatura en la época de Sancho IV. Actas del Congreso Internacional (Alcalá de Henares, 21-24 de febrero de 1994), Alcalá de Henares, 1996, 107-120.

42 Glosa castellana..., p. 286 y s.; y Castigos y documentos (ed. P. DE GAYANGos: Escritores en prosa..., 79-228), p. 196; otra edición crítica más reciente es la de H.O.: BIzZARRI: Los castigos del rey don Sancho IV: una reinterpretación, Londres, 2004. Las similitudes entre los dos tratados han sido estudiadas, a través de un método comparativo, Por P. Groussac: "Le Livre des castigos e documentos attribué au Roi D. Sanche IV" y R. Foulché-Delbosch: "Les Castigos e documentos de Sanche IV', en Revue hispanique, 15, 1906, 212-339 y 340-371 respectivamente. 


\author{
EGIDIO ROMANO \\ De regimine principum
}

"En las costumbres de los ommes todos los extremos son malos, ca toda sobrepujanza e todo fallescimiento que es en cualquier obra es de denostar e el medio es de loar. E según el Filósofo, toda virtud está en el medio y por ende es esta regla general para conocer todas las pasiones".

"De las virtudes nascen virtudes e de los pecados nascen pecados, ca todas las virtudes se acompannan en uno con obra maravillosa, según que dice San Agustín”.

\section{SANCHO IV \\ Castigos y documentos}

A mediados del siglo XIV, el franciscano Juan García de Castrojeriz traduce y añade comentarios personales al libro de Egidio en su Glosa castellana o Del regimiento de los príncipes y señores que han de regir a otros ${ }^{43}$, una tarea encargada por el Obispo de Osma don Bernabé para instrucción del infante don Pedro, hijo de Alfonso XI y futuro monarca. Aunque esta sea la versión más extendida de la obra de Egidio en los reinos ibéricos, también existen otras ediciones como la francesa de Henri du Gauchy, Livre du gouvernement de rois, documentada en la biblioteca del Marqués de Santillana, o la catalana del carmelita Arnau Stanyol, elaborada en 1430 para don Jaime, el último Conde de Urgell, durante su arresto por enfrentarse a Fernando de Antequera ${ }^{44}$. También en Portugal se lee a Egidio a través del Livro da virtuosa benfeitoria del infante don Pedro (1418) y de Leal conselheiro del infante Duarte (ca. 1438).

El prestigio que goza Egidio entre los autores hispanos puede comprobarse también en el elevado número de alusiones que posee. Don Juan Manuel, por ejemplo, insiste en el Libro infinido sobre el interés de su obra para el aleccionamiento político $(1336)^{45}$ :

"Et si quisiéres saber quales son las maneras et las costumbres de los buenos reyes et de los tiranos, et que diferencia es entre ellos, fallarlo sin hedes en el libro que fizo Fray Gil, de la Orden de Sant Agostín, que llaman De regimine principum, que quiere dezir Del governamiento de los Príncipes".

Igualmente Pero López de Ayala recomienda su lectura en uno de los versos de su Rimado de palacio $(1385-1403)^{46}$ :

43 Vid. M.J. Díez Garretas: “Juan García de Castrojeriz, ¿traductor de Egidio Romano?”, en C.M. ReGLEro De La Fuente (Coord.): Poder y sociedad en la Baja Edad Media hispánica. Estudios en homenaje al profesor Luis Vicente Diaz Martín, I, Valladolid, 2002, 133-141.

44 Vid. G. Díaz Díaz: Hombres y documentos de la Filosofía española, VII, Madrid, 2003, p. 377.

45 Libro infinido (ed. P. De Gayangos: Escritores en prosa..., 264-275), p. 268.

${ }^{46}$ Rimado de palacio (ed. VV.AA., Madrid, 2011), copla 625, p. 128. 


\begin{abstract}
"Qual regimiento deven los príncipes tener, es escripto en los libros que solemos leer.

Egidio el Romano, omne de grant saber, in Regimini principum lo fue bien componer".
\end{abstract}

Otros autores que emplean con frecuencia su speculum son Rodrigo Sánchez de Arévalo $^{47}$, Diego de Valera ${ }^{48}$, Alfonso Fernández de Madrigal (Comentario al tratado sobre el Regimiento de los Príncipes de Egidio Colonna) o Pedro de Chinchilla (Exortaçión o ynformación de buena e sana doctrina); sabemos, además, que el rey Juan I de Portugal le cita en el discurso que pronuncia ante los caballeros que participan en la toma de Ceuta ${ }^{49}$.

Los autores posteriores a Brunetto y Egidio apenas introducen novedades significativas en sus disertaciones sino que, como ellos, elaboran una reducción de Aristóteles. No obstante, también escriben sobre otras cuestiones relacionadas y de gran interés como la naturaleza del poder político, los estamentos sociales o análisis de leyes. Una muestra al respecto es el Defensor pacis (1324) de Marsilio de Padua (ca. 1275-1343), cuya primera parte censura las injerencias del Papado en el Imperio (téngase en cuenta el tenso contexto del pontificado de Juan XXII y la labor asesora del autor a Luis IV) y segunda expone el modelo aristotélico para el gobierno urbano, defendiendo especialmente el derecho de la ciudadanía a estar presente en el consejo de jurados a través de unos representantes electos ${ }^{50}$.

Igualmente destaca por su originalidad la obra del jurista Bartolo de Sassoferrato (1313-1357), gran conocedor del Derecho Romano, profesor en varias escuelas italianas y asesor del emperador Carlos IV. Sus dos tratados más importantes son De nobilitate (ca. 1344) y De insigniis et armis (ca. 1356); Diego de Valera los conoce y los emplea como fuente recurrente para defender los méritos por hechos propios sobre el principio de linaje en la concesión de la dignidad nobiliaria.

Finalmente, Coluccio Salutati (1331-1405) está al frente de las cancillerías de Lucca y Florencia así como de varias escuelas de Retórica y Oratoria donde conoce como alumno al aretino Leonardo Bruni (1379-1444), delegado papal por recomendación de Poggio Bracciolini y gran traductor de la obra política de Aristóteles. Ni Salutati ni Bruni cultivan el tema del gobierno urbano de manera directa en sus composiciones, si bien resulta posible encontrar algunas referencias sobre su pensamiento al respecto, ninguna novedosa, en De nobilitate legum (1399) y De tyranno (1400) del primero, o De militia (1422) e Historiarum florentinarum (ca. 1403) del segundo.

47 En el siguiente apartado se ofrecerán cuadros comparativos sobre los contenidos de los tratados de ambos autores.

48 Vid. Doctrinal de principles (ed. M. PENNA: Prosistas castellanos..., 173-202), p. 191.

49 Vid. el estudio preliminar de la edición de J. BeneYto PéreZ, pp. XIX y XXIV; y, en conclusion sobre el impacto de Egidio en la Península Ibérica, el artículo de F. RuBIo: "De regimine principum de Egidio Romano en la Literatura castellana de la Edad Media”, La Ciudad de Dios, 173, 1960, 32-71.

50 Vid. ed. Madrid, 1989. Sobre la importancia del autor en la Historia del pensamiento político vid. F. Gentile: "Sulla struttura ideologica della dottrina politica di Marsilio da Padova", en VV.AA.: Diritto, persona e vita sociale. Scritti in memoria di Orio Giacchi, Milán, 1984, 558-564; y J.R. García CuE: "Teoría de la ley y de la soberanía popular en el Defensor pacis de Marsilio de Padua", Revista de estudios políticos, 43, $1985,107-148$. 
Bruni es profesor de Lorenzo Valla (1407-1457), famoso por sus usos de la crítica filológica como método de análisis histórico; en algunos de sus textos, como la Gesta Ferdinandi regis Aragonum, también es posible encontrar algunas opiniones sobre la representación del buen político ${ }^{51}$. Mención aparte merece Il principe de Maquiavelo (1469-1527), que redactado en 1513 y publicado en 1531, nos permite establecer el hito final de este repaso.

\subsection{LOS TRATADOS HISPÁNICOS: SU CARACTERIZACIÓN}

Los autores peninsulares de la Baja Edad Media que escriben sobre cómo gobernar la ciudad pueden clasificarse en dos grupos. El primero de ellos integra a traductores o glosadores de los tratados europeos mencionados en el apartado anterior (Sancho IV, Pero Gómez Barroso, Pedro de Portugal, Juan García de Castrojeriz, Alfonso Fernández de Madrigal, Arnau Stanyol y Duarte de Portugal). El segundo, objeto de nuestro interés, agrupa, por el contrario, a aquellos que introducen nuevas aportaciones en tratados originales, si bien en la mayoría de los casos básicamente sintetizan Las Partidas y los textos legales básicos (Ramón Llull, don Juan Manuel, Francesc Eiximenis, Juan de Alarcón, Alonso de Cartagena, Rodrigo Sánchez de Arévalo y Diego de Valera). Otros tratadistas que también escriben sobre la ciudad, aunque sin ser esta la temática central de su obra, son Clemente Sánchez Vercial, Alonso Díaz de Montalvo, Pedro de Chinchilla, Alonso Ramírez Villaescusa o Alonso Ortiz de Urrutia.

El mallorquín Ramón Llull (1232-1315) es uno de los filósofos más destacados del Medioevo hispánico. Su obra se caracteriza por la orientación pedagógica y misionera, siendo su intención principal exponer los beneficios que entraña la conversión sincera al Cristianismo; junto al sermón trata también temas morales e intelectuales (Teología, Filosofía Natural, Artes Liberales...) por medio de parábolas y enxemplos didácticos ${ }^{52}$. A pesar de ello es posible hallar referencias sobre la ciudad ideal en cuatro de sus tratados. El primero de ellos, siguiendo un criterio cronológico, es Doctrina pueril (1275), texto dedicado a su hijo Domènec cuya primera parte expone los mandamientos, los pecados capitales y los principios credenciales de la fe católica, y segunda define las artes del Trivium y del Quadrivium. El único capítulo relacionado con los gobernantes es el LXXX, de doce ítems y dedicado a sus competencias morales $^{53}$.

Coetánea a la obra anterior es el Libre de l'ordre de cavalleria (1275), una de las piezas más interesantes de la literatura medieval peninsular para comprender el uni-

51 Vid. ed. S. López Moreda: Gesta Ferdinandi regis Aragonum, Madrid, 2002. El mismo autor analiza la caracterización del gobernante ideal en la crónica en su artículo "El modelo de princeps en la obra histórica de Lorenzo Valla", Humanitas, 56, 2004, 401-423.

${ }^{52}$ Un estado de la cuestión sobre estudios lulianos en M.r. Ripoll Perelló (Coord.): Actes de les Jornades Internacionals Lul.lianes: Ramón Llull al segle XXI (Palma de Mallorca, 1-3 d'abril de 2004), Palma de Mallorca, 2005 (Quaderns de la Mediterrània, 9); vid., sobre su vida y relevancia filosófica, las síntesis de J.N. Hillgarth: Ramon Llull i el naixement del lul.lisme, Barcelona, 1998; y L. Badia Pamiés: Ramón Llull: vida, pensament $i$ obra literaria, Barcelona, 1988.

53 Vid. ed. M. Batllori: Ramón Llull: obra escogida, Barcelona, 1981, 265-308 (fragmentos). 
verso mental de la nobleza defensiva ${ }^{54}$. Organizado en siete amplios capítulos, narra como un escudero atraviesa un bosque rumbo a la corte en la que va a ser armado topándose con un filósofo que le enseña todo lo concerniente a su estado. El caballero, explica Llull, al ostentar poderes defensivos y gubernamentales, debe definirse por un código de actitudes morales (espejo ético), funcionales (garantizar la paz) y devotas (defender la fe) que le permita tomar conciencia de sus responsabilidades sociales (expuestas en el cap. II) ${ }^{55}$, de la importancia de su educación, formación intelectual y vocación cristiana (cap. III), así como de sus costumbres y virtudes morales (cap. VI).

Por su parte, el Libre de contemplació en Déu (1276) ofrece una visión del orden social desde el punto de vista de la ética filosófica. Expone, así, los tipos de trabajadores y sus funciones orgánicas, comenzando con los jueces, abogados y médicos para proseguir con el de los mercaderes, artesanos, agricultores, carpinteros, albañiles, pe1literos, herreros y demás menestrales urbanos ${ }^{56}$. Esta temática la retoma en el Arbre de la ciencia (1296), especialmente en el libro III (De los brazos del árbol imperial), que contiene enseñanzas relativas a la naturaleza, el mundo sensible e inteligible, el individuo, la moral humana, el gobierno, la Iglesia... ${ }^{57}$ En suma, la obra de Ramón Llull responde a una pretensión teológica y filosófica, de modo que apenas dedica espacio a asuntos terrenales. Aún así es posible encontrar en ella tres definiciones básicas que nos sirven como reflexiones introductorias a la tratadística sobre gobierno que eclosiona en la Baja Edad Media: considera la "política" el arte que procura el bien público de las ciudades, el "regimiento" la forma con la que el gobernante rige su pueblo, y la "caballería" el hábito con el que el caballero contribuye al mantenimiento de la justicia ${ }^{58}$.

La tratadística de la primera mitad del siglo XIV castellano está protagonizada por la figura de don Juan Manuel (1282-1348) ${ }^{59}$. Hijo del duque don Manuel de Villena y de Beatriz de Saboya, nieto del rey Fernando III de Castilla y del conde Amadeo IV de Saboya, y sobrino de Alfonso X, don Juan Manuel recibe una educación propia de príncipes en la casa de Juan Sánchez de Ayala, es corregente del reino durante la

54 Vid. ed. L.A. De Cuenca, Barcelona, 1947. Un esbozo sobre la doctrina luliana, vid. J. Maíz Chacón: "La argumentación filosófica del caballero medieval. El modelo e ideal luliano en el Libre del Orde de Cavaleria", Mirabilia. Revista eletrônica de História Antiga e Medieval, 5, 2005, disponible On-line en <http://www. revistamirabilia.com/nova/images/numeros/2005_05/05.pdf $>$ [con acceso el 3-X-2012].

55 Estas son mantener y defender la santa Fe católica (II, 2); mantener y defender a su señor terrenal (II, 8); mantener la justicia (II, 9); mantener la tierra (II, 12), es decir, garantizar la paz y bien común; mantener viudas, huérfanos y pobres (II, 19); tener castillo y caballo para guardar caminos y defender a los labradores (II, 22); tener villas y ciudades con el fin de regir a las gentes (II, 22); y destruir a los malvados (II, 23). En el próximo apartado se ampliará información al respecto.

56 Vid. ed. J. Gaya Estelrich: Libre de contemplació en Déu, 8 vols., Palma de Mallorca, 2000.

57 Vid. ed. M. BAtLlori: Ramón Llull..., 495-571 (fragmentos).

58 Definiciones tomadas del Ars brevis; para una aproximación al pensamiento político de Llull vid. M. Cruz Hernández: El pensamiento de Ramón Llull, Valencia, 1977, pp. 301 y ss.; y M. SANChIS GuARNER: "L'ideal cavalleresc definit per Ramon Llull", Estudios lulianos, 2, 1958, 37-62.

59 Una síntesis sobre su obra en M. Gaibrois De BALlesteros: El príncipe don Juan Manuel y su condición de escritor, Madrid, 1945; una miscelánea de estudios sobre sus contribuciones literarias en VV.AA.: Don Juan Manuel, VII Centenario, Murcia, 1982 (destacamos la contribución de L. De Stefano: "Don Juan Manuel y el pensamiento medieval", pp. 337-352). 
minoría de edad de Alfonso XI y cabeza titular del poderoso Señorío de Villena ${ }^{60}$. Su obra, pilar referencial de la concepción tradicional de la sociedad y mentalidad nobiliaria, se detiene ampliamente en las temáticas de gobierno pero es muy escueta en lo relacionado con el ámbito urbano.

Inspirándose en el contenido y estilo literario del Libre de l'ordre de cavalleria de Lull, compone para su cuñado el Arzobispo de Toledo el Libro del caballero et del escudero (1326-1328) ${ }^{61}$. Consta de cincuenta y un capítulos, de los cuales se han perdido trece (del 3 al 16), en los que afronta las bases del oficio y educación caballeresca, dedicando una breve mención a los deberes sobre gobernación al final de la obra. No obstante, el texto con más información y que mejor desvela el pensamiento del autor es el Libro de los estados (1327-1332), también titulado Libro del Infante ${ }^{62}$. Como ya se ha mencionado, el planteamiento adapta las líneas argumentales de la leyenda de Barlaam e Josafat: el rey Morován encarga a Turín la educación de su hijo Juan bajo la orden expresa de que no le enseñe nada sobre dolores y placeres humanos por temor a la corrupción; siendo joven, el infante encuentra un muerto y, atónito, escapa de su casa para criarse bajo la protección de Julio, su verdadero maestro, quien le trasmite el conocimiento verdadero. Así, el primer libro incluye adoctrinamiento moral e instrucción política; expone los principios básicos de la existencia, los pilares credenciales del Cristianismo y la jerarquía de los estados sociales, estando los capítulos LXXXI-C dedicados a la actividad regidora ${ }^{63}$. Por su parte, el segundo libro no ofrece interés para nuestro estudio al centrarse exclusivamente en cuestiones devotas y de jerarquía eclesiástica.

Desde el punto de vista de la creatividad literaria, el Libro de Patronio o El conde Lucanor (1330-1335) es la obra culminante del autor ${ }^{64}$. En él, Patronio aconseja a Lucanor sobre cómo actuar en diferentes situaciones a través de breves historias, unas reales y otras ficticias, que poseen una moraleja adecuada a sus circunstancias. Todos los capítulos finalizan con un enxemplo o proverbio didáctico que el noble puede aplicar bien a su vida personal, bien a su oficio: carácter individual, cualidades y destrezas de los magistrados, gestión de recursos territoriales, relaciones sociales con los vasallos y otros hombres del mismo estado... Finalmente, el Libro infinido o Libro de los castigos o consejos (1336) plantea un bosquejo esquemático de toda su obra anterior a su hijo Fernando (1332-1350), su sucesor en el Señorío de Villena ${ }^{65}$.

Si don Juan Manuel es el compositor más notorio del Trescientos castellano, el franciscano gerundense Francesc Eiximenis (1327-1409) lo es de la corona aragone-

${ }^{60}$ La biografía política de don Juan Manuel en el contexto de la coyuntura social del siglo XIV en J.R. Araluce Cuenca: El "Libro de los estados". Don Juan Manuel y la sociedad de su tiempo, Madrid, 1976; y J. VAldeón Baruque: "Las tensiones sociales en Castilla en tiempos de don Juan Manuel”, en I. MACPHERSON (Coord.): Don Juan Manuel studies, Londres, 1977, 181-192.

${ }^{61}$ Vid. ed. P. De Gayangos,: Escritores en prosa..., 234-257.

62 Vid. ed. ibidem, 278-364.

${ }^{63}$ Vid. Libro de los estados, pp. 327 y ss., sobre qué cosas ha de facer el señor para ser amado et recelado denlos suyos. Remito al trabajo, antiguo pero todavía válido, de J.M. Castro y Calvo anteriormente expuesto.

64 Vid. ed. P. De Gayangos: Escritores en prosa..., 367-439.

65 Vid. ed. ibidem, 264-275. 
$\mathrm{sa}^{66}$. A lo largo de su biografía reside en Barcelona, Valencia, París, Oxford, Colonia así como diversas poblaciones italianas donde estudia Artes, Teología y actúa como embajador áulico; la disposición urbanística y el modelo de gestión gubernamental de estas ciudades influyen decisivamente en su personalidad como teórico intelectual. Su labor como consejero real (trabaja al servicio de Pedro IV, Juan I, Martín I y del Papa Benedicto XIII) está claramente orientada hacia la predicación religiosa. Su obra más importante es el Crestià, una enciclopedia de trece volúmenes sobre los saberes universales de la que tan sólo se conservan los tres primeros tomos y el duodécimo. Este último, redactado entre 1385 y 1386 aunque con añadidos hasta 1392, también recibe el título de Libre de regiment dels princeps e de comunitats y, como el propio nombre indica, está dedicado enteramente al gobierno de la ciudad, siendo la tercera de las ocho partes que lo constituyen (capítulos CCLVII-CCCLXIV) el famoso Regiment de la cosa publica (1383) que tantas veces se ha estudiado como tratado independiente por su orientación expresa a instruir a los jurados de Valencia en el ejercicio de sus responsabilidades ${ }^{67}$.

El arquetipo de urbe y sociedad ideal de Eiximenis reposa tanto en concepciones propias como en ideas de filósofos antiguos y cristianos, entre los que destacan Aristóteles y San Agustín, a los que acude para establecer una definición de ciudad y de cosa publica tanto desde el punto de vista material como espiritual (...es una comunidad de gente reunida que viven bajo una misma ley, señoría y costumbres, entendiendo por tal reunión reino, ciudad, villa, castillo, o cualquier comunidad parecida que no sea una sola casa... $)^{68}$; también para argumentar los beneficios de su existencia y habitación, describir la relación entre la villa y su entorno geográfico, aconsejar sobre la disposición de los espacios intramuros (orientación de murallas, plazas, edificios y huertas), concretar las actividades económicas y de ocio necesarias, delimitar las encomiendas de cada grupo social y en especial de los regidores. Asimismo defiende un modelo organicista en el que cada individuo desempeña un cometido concreto y necesario para el correcto funcionamiento del sistema; su explicación, inspirada en Egidio y Aristóteles, establece una analogía con las extremidades del cuerpo humano: todas ellas llevan a cabo funciones igualmente importantes y están interconectadas con las demás (por ejemplo, las piernas necesitan de los ojos para saber por qué camino es más seguro andar, deducción que sólo es posible con el cerebro, órgano principal que representa al gobernante) ${ }^{69}$.

66 Sobre su vida y obra vid. La monografía de R. FERrer NAVARro: Eiximenis i la seua obra, Valencia, 2010; y los artículos de X. Renedo I Puig: "Cinc estudis sobre Francesc Eiximenis", Caplletra. Revista internacional de Filología, 48, 2010, 129-133; o P. SAntonja: "Francesc Eiximenis y su época: finales del siglo XIV y principios del siglo XV", Azafea. Revista de Filosofía, 2, 1989, 19-35.

67 Vid. ed. A. CAlderó I CABrÉ: Regiment de la cosa publica, Barcelona, 1999; una edición más reciente es la de A. Hauf I Valls, V. Martines Peres y E. SÁnchez López: Lo regiment de la cosa publica en el "Dotzè”, del "Crestià". El gobierno de lo público en el "Duodécimo" del "Cristiano", Madrid, 2009. Valencia, en estos momentos, conoce varios bandos nobiliarios enfrentados por deseo de acaparar poder, de modo que con este libro el autor pretende puntualizar las responsabilidades objetivas del gobernante perfecto para normalizar la situación conforme a los preceptos teóricos. Un estudio reciente sobre los jurados valencianos es el de R. Narbona Vizacino: "Cultura política y comunidad urbana, Valencia siglos XIV y XV”, Edad Media. Revista de Historia, 14, 2013, 171-211.

68 Regiment de la cosa publica, p. 75.

${ }^{69}$ Ib., p. 111. El texto en columnas, Glosa castellana..., p. 628; y Regiment de la cosa publica, p. 79. 
"Tanta es la nobleza de la cosa pública bien regida y tanto es el provecho que se sigue a todos en general y a cada uno en especial, que todos cuantos están en la comunidad, grandes y pequeños, viejos y jóvenes, pobres y ricos, hombres y mujeres, clérigos y seglares, señores y vasallos, todos han de ayudar con todo su poder y saber: los viejos con su consejo y juicio; los jóvenes con su fuerza y vigor; los pobres según su facultad; los ricos con sus riquezas; los hombres con todo lo que saben y les es mandado; las mujeres, dejando inútiles ornamentos, perlas y otras cosas, para no cargar a sus maridos de gastos; los clérigos con sus oraciones continuas; los seglares con armas y diversos otros trabajos, hasta que la comunidad esté en buen estamento".

\section{EGIDIO ROMANO \\ De regimine principum}

"El príncipe tiene lugar de cabeza; los adelantados e los merinos tienen lugar de orejas porque resciben los mandamientos del rey en cómo fagan la justicia e guardan la tierra; los jueces e los alcaldes tienen lugar de los ojos, porque deven ver a luenne en cuál manera juzguen los pueblos; los sabios e los abogados tienen lugar de la lengua; los consejeros tienen lugar del corazón; los caballeros que han de defenderse han manera de manos; los labradores e los oficiales se han a manera de pies, que andan por la tierra trabajando e sufriendo el cuerpo. E de todas estas maneras hay muy notables sentencias".

\section{FRANCESC EIXIMENIS Regiment de la cosa publica}

"En la cosa pública había una cabeza, que es aquella que tiene el regimiento y la señoría; los ojos y las orejas son los jueces y los oficiales; los brazos son aquellos que defienden la cosa pública, estos son los caballeros y los hombres de armas; el corazón son los consejeros; las partes generativas son los predicadores y los informadores; los muslos y las piernas son los menestrales; los pies que pisan la tierra son los labradores que la cultivan y la trabajan por su oficio siempre".

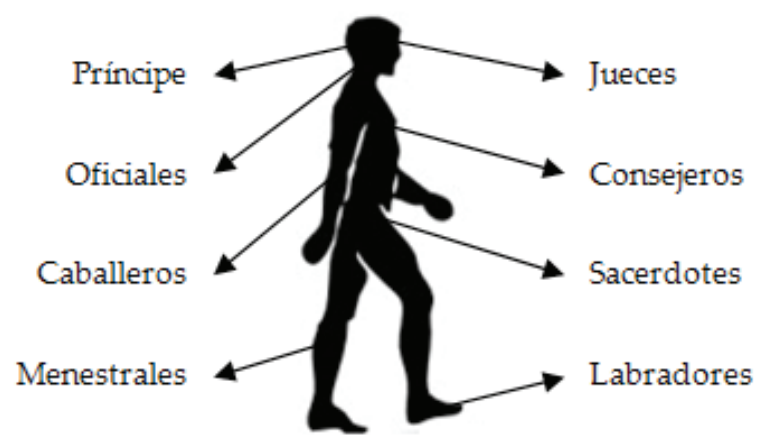

Silueta orgánica del orden social según el Regiment de la cosa publica de Francesc Eiximenis (1383)

Al margen de los asuntos puramente políticos, el catalán subraya otras ideas que considera esenciales entre las preocupaciones de los gobernantes para el correcto funcionamiento de la ciudad como son la protección de los estudiantes y desam- 
parados (viudas, enfermos y peregrinos), el castigo a los ociosos y delincuentes, la persecución de la inmoralidad en la conducta, la promoción de la burguesía financiera y mercantil mediante un régimen político-económico acorde a sus intereses o la participación de la ciudadanía en la elección de los jurados ${ }^{70}$.

Todos estos contenidos sólo vuelven a ser tratados con el mismo detalle y cuidado que Eiximenis por el teólogo, delegado de Castilla en el extranjero, obispo de varias sedes y alcaide del Castel Sant'Angelo Rodrigo Sánchez de Arévalo (1404-1470) ${ }^{71}$; su larga estancia en Roma le permite entablar amistad con números humanistas italianos, conocer directamente su obra y la de muchos autores clásicos. La ciudad como tema lo trata en la Suma de la politica (1455), un discurso en dos libros para Pedro Dacuña, Señor de Dueñas y Buendía, también miembro del Consejo Real, en el que le instruye sobre materia gubernamental ${ }^{72}$.

El libro I, fuertemente influenciado por Aristóteles y Egidio, está dedicado a la organización no institucional de la ciudad. En los capítulos I-VI ubica geográficamente un enclave urbano modélico precisando las regiones idóneas para su fundación, la orientación de su plano y los recursos naturales que ha de haber en sus proximidades (bosques, montes, tierras de labranza y agua potable); cabe destacar que Eiximenis aborda estas mismas cuestiones de manera mucho más pormenorizada que Arévalo ${ }^{73}$.

70 El hecho de que Eiximenis sea, a nuestro juicio, junto a Rodrigo Sánchez de Arévalo, el tratadista peninsular más importante para el estudio de la ciudad ideal a finales de la Edad Media ha suscitado diversos estudios sobre su pensamiento; a modo de referencia general destacan las monografías de J.L. MARTín: La ciudad y el príncipe. Estudio y traducción de los textos de Francesc Eiximenis, Barcelona, 2004 (el mismo autor se detiene en la caracterización moral de la nobleza regente en su artículo "El tratado de caballería de Francesc Eiximenis", Norba, 16.1, 1996-2003, 295-331); y L. CERVERA VERA: Francesc Eiximenis y su sociedad urbana ideal, Madrid, 1989. Sobre sus ideas sobre morfología de la ciudad vid. S. VILA: La ciudad de Eiximenis: un proyecto teórico de urbanismo en el siglo XIV, Valencia, 1984. En lo relativo al papel de Eiximenis como pensador político, vid. dos trabajos básicos: A. LóPEZ-AMO y MARíN: "El pensamiento político de Eiximenis en su tratado Regiment de Prínceps", Anuario de Historia del Derecho español, 17, 1946, 5-139; y J.A. MARAVALL: "Franciscanismo, burguesía y mentalidad precapitalista: la obra de Eiximenis", Estudios de Historia del Pensamiento español. I: Edad Media, Madrid, 1973, 393-412. Más recientes son los trabajos de C. VILANOU Torrado: "El Humanismo de Eiximenis: saber, ciudad y cortesía", Historia de la educación. Revista interuniversitaria, 31, 2012, 135-163; y C. MANCINELI: "Francesc Eiximenis y su programa pedagógico", Forma. Revista d'estudis comparatis: Art, Literatura, Pensament, 3, 2011, 101-109.

71 Sobre el protagonismo de Arévalo en el humanismo español del siglo XV vid. R.H. TramE: Rodrigo Sánchez de Arévalo (1404-1470). Spanish Diplomat and Champion of Papacy, Washington, 1958; y del mismo autor, "La carrière d'un diplomat espagnol au XV siècle (1435-1479)", Revue d'Histoire Diplomatique, 1962, 76, 227-254; T. TONI: “Don Rodrigo Sánchez de Arévalo, 1405-1470”, Anuario de Historia del Derecho español, 12, 1935, 97-360; la monografía de J.M. LABOA: Rodrigo Sánchez de Arévalo, alcaide de Sant'Angelo, Madrid, 1973; o las conclusiones de L. VelÁzQuEz: "Rodrigo Sánchez de Arévalo", en M. FARTOS Martínez (Coord.): La Filosofía española en Castilla y León: de los orígenes al Siglo de Oro, 1997, $121-136$.

72 Vid. M. Penna: Prosistas castellanos..., 249-309.

73 Un análisis comparativo de ambos tratados en A. Antelo IgLESIAS: "La ciudad ideal según fray Francesc Eiximenis y Rodrigo Sánchez de Arévalo", En la España medieval, 6, 1985, 19-50. También se estudia a fondo la obra del segoviano en A.I. CARRASCO MANCHADO: "Análisis de las fuentes literarias castellanas para la historia de la cultura política en la Edad Media: el ejemplo de política, políticos, politizar", en M.C. FERNÁNDEZ LóPEZ, M. SuÁrez Fernández, A. Veiga (Coords.): Oh Lux Iberiae. En torno a las letras en la España Medieval, Lugo, 2013, 181-201: J.A. BonACHÍA HERNANDO: "Entre la «ciudad ideal» y la «sociedad real»: consideraciones sobre Rodrigo Sánchez de Arévalo y la Suma de la Política, Studia Historica. Historia Medieval, 28, 2010, 23-54; L. Cervera Vera: "La ciudad ideal concebida en el siglo XV por el humanista Sanchez de Arévalo", Boletín de la Real Academia de la Historia, 179.1, 1982, 1-34. 
Los capítulos VII-X sintetizan las tareas atribuidas a cada grupo social urbano; así, los regidores gobiernan la ciudad, los caballeros garantizan su defensa y los eclesiásticos velan por la salud espiritual de sus habitantes; el resto de la población practica oficios como la provisión de vestido (lanificium), el abastecimiento de alimento (victuaria: agricultura y venatio), el suministro de mercancías (negotiatoria) $)^{74}$, la construcción de viviendas (armatura), el cuidado de enfermos (medicina) y el entretenimiento saludable de las gentes (theatrica). Arévalo expone esta doctrina sobre las Artes Mecánicas en su obra culminante sobre Teología moral, Speculum vitae humanae (1468), siendo sus principales antecedentes Hugo de San Víctor (ca. 1096-1141), Radulfo de Campo Lungo (1155-1215), Vincent de Beauvais (ca. 1190-1267) y Ramón Llu$11^{75}$. Los capítulos XI-XVI recopilan una selección de consejos del primer libro del Epitome de re miliari de Vegecio (siglo IV) encaminados a preparar a la ciudad ante un eventual ataque enemigo: población instrumentada, defensas infraestructurales, tesoro público con fondos para eventualidades... si vis pacem para bellum, o en palabras de Arévalo, felix civitas que tempore pacis que tempore pacis bellum cogitat ${ }^{76}$; las virtudes del capitán militar se especifican en los ítems XIII-XIV. Finalmente, los capítulos XVI-XVII resumen las ideas de Bruni y Sassoferrato sobre los orígenes y funciones de la caballería; será Diego de Valera quien exponga con más énfasis estas cuestiones, como se señalará más abajo.

El libro II de la Suma de Arévalo versa sobre política urbana. En él caracteriza los dones del gobernador (capítulos I-III), de sus asesores (IV-VI), de los jueces (VI-XI) y de los vasallos (XII-XVI). Este esquema cuádruple parte del sexto libro de la Politica aristotélica, pasaje que explica cómo intervienen cuatro elementos humanos con competencias expresas en la polis: el príncipe (regir la ciudad por medio de leyes), los consejeros (velar para que las leyes sean las adecuadas), los jueces (juzgar las obras de los hombre según las leyes ordenadas) y los ciudadanos (guardar los mandamientos de las leyes). Toda la tratadística que recibe la influencia de Egidio, refundi-

${ }^{74}$ En sintonía con la doctrina de Eiximenis, Arévalo explica que en el comercio se encuentra la clave del éxito urbano. Esta actividad (cambios, comutaciones y vendiciones) debe cumplir el fin abastecedor de la ciudad sin fines lucrativos; sólo cuando el enclave no dispone de recursos para la autosuficiencia se aprueba los intercambios comisionistas (negociatoria).

${ }^{75}$ Vid. Doctrina pueril, pp. 303 y ss. Llull enumera y explica brevemente cuáles son los oficios necesarios para cubrir las necesidades básicas de la vida en la ciudad. Para comprender la voluntad de dignificación de las artes manuales por parte de los autores mencionados vid. P. DuHAmEL: "Les arguments de l'insertion des Artes Mécaniques dans le Didascalicon de Hugues de Saint-Victor", Memino, travaux el documents, 2, 1998, 127-138; S. Lusignan: "Les arts mécaniques dans le Speculum doctrinale de Vincent de Beauvais", Cahiers d'études médiévales, 7, 1982, 33-48; R. DA Costa: "Las definiciones de las siete Artes Liberales y Mecánicas en la obra de Ramón Llull”, Anales del Seminario de Historia de la Filosofía, 23, 2006, 131-164; y V. MuÑoz Delgado: "Las Artes Mecánicas y Liberales en Rodrigo Sánchez de Arévalo”, Studia Zamorensia, 4, 1983, 35-61.

76 Suma de la politica, p. 269 (bienaventurada y fortunada es la ciudad que en tiempo de paz piensa la guerra). Vegecio ofrece esta sentencia en la introducción al tercer libro de su Epítome. La transcriben, entre otros muchos, don Juan Manuel (El que quiere vevir en paz que se apareje para la guerra; Libro del caballero et del escudero, p. 254), Juan Gil de Zamora (Qui desiderat pacem preparet bellum; De praeconiis Hispaniae, libro IX, título 10), o el propio Rodrigo Sánchez de Arévalo (Quien desea la paz, apareje la guerra; Vergel de príncipes, p. 319). 
dor de Aristóteles, repite el mismo esquema fielmente, siendo un claro ejemplo de la dependencia hacia el filósofo griego ${ }^{77}$.

\begin{tabular}{|c|c|c|}
\hline \multicolumn{2}{|c|}{ DEPENDENCIA Y EQUIVALENCIA ENTRE LA TRATADÍSTICA HUMANISTA Y LA } \\
POLÍTICA DE ARISTÓTELES: EGIDIO ROMANO Y RODRIGO SÁNCHEZ DE ARÉVALO \\
\hline & $\begin{array}{c}\text { EGIDIO ROMANO } \\
\text { De regimine principum }\end{array}$ & $\begin{array}{c}\text { R. SÁNCHEZ DE ARÉVALO } \\
\text { Suma de la politica }\end{array}$ \\
\hline Parte principatoria & Libro III, parte II, caps. 1-15 & Libro II, caps. 1-3 \\
\hline Parte consiliatoria & Libro III, parte II, caps. 16-19 & Libro II, caps. 4-6 \\
\hline Parte judicatoria & Libro III, parte II, caps. 20-31 & Libro II, caps. 7-11 \\
\hline Parte popular & Libro III, parte II, caps. 32-36 & Libro II, caps. 12-16 \\
\hline
\end{tabular}

Arévalo comienza con una brevísima explicación de las razones por las cuales es más deseable la existencia de un solo poder político en la ciudad en lugar de varios que, procedentes de una misma o diferente institución, pueden enfrentarse entre sí y provocar el empobrecimiento del enclave. Esta problemática la explica con todo detalle en el Liber de regno dividendo (1467-1468), escrito para el Obispo de Calahorra y Sigüenza Pedro González de Mendoza en un contexto de superposición de poderes supremos: tensiones entre Papado e Imperio, y dos reyes enfrentados y desautorizados (Enrique IV y el infante don Alfonso) ${ }^{78}$. Su propósito es esgrimir, a partir de opiniones de otros filósofos ${ }^{79}$, razones a favor y en contra de la existencia de dos poderes soberanos en un mismo territorio, así como presentar algunas ideas sobre el heredamiento de jurisdicciones.

${ }^{77}$ La equivalencia entre el texto de Egidio y el del infante Pedro de Portugal en F.E. Tejada: "Ideologia e utopia no Livro da virtuosa benfeitoria", Revista portuguesa de Filosofia, 3, 1947, 5-19.

${ }^{78}$ Vid. ed. J.A. SolóRZAno Telechea: Tratado sobre la división del reino y cuándo es lícita la primogenitura, Logroño, 2011; con la traducción a cargo de J.C. Miralles Maldonado.

${ }^{79}$ Entre las fuentes empleadas por Arévalo, además de la Biblia y de los dos pensadores medievales más influyentes (San Agustín y Santo Tomás), se encuentran Aristóteles, Demócrito, Demóstenes, Licurgo, Platón, Polícrates, Solón, Hipócrates, Séneca, Catón, Cicerón, Salustio, Jenofonte, Virgilio, Frontino, Macrobio, Tito Livio, Paladio, Valerio Máximo, Trogo Pompeyo, Vegecio, Cipriano, San Jerónimo, San Gregorio Magno, Pedro Damiano, San Buenaventura, San Ambrosio, Juan Crisóstomo, San Isidoro, San Alberto Magno, Bartolomé de Glanville, Giovani d'Andrea, Vincent de Beauvais, San Bernardo, Rábano Mauro, Honorio de Autun, Averroes, Cino di Pistoloa, Enrique de Susa, Ángelo de Ubaldis, Dino de Mugello, Marsilio de Padua, Francesc Eiximenis, Egidio, Bartolo de Sassoferrato, Oldrado de Ponte, Guildo de Bayslo, Francisco de Mayrones, Francisco de Zabarellis... así como otros coetáneos. Vid. Tratado sobre la división del reino, p. 32 y s. 


\begin{tabular}{|l|l|l|l|}
\cline { 3 - 4 } \multicolumn{1}{l|}{} & $\begin{array}{l}\text { ARISTÓTELES } \\
\text { Políticas }\end{array}$ & $\begin{array}{l}\text { EGIDIO ROMANO } \\
\text { De regimine principum }\end{array}$ & $\begin{array}{l}\text { R.S. DE ARÉVALO } \\
\text { Liber de regno } \\
\text { dividendo... }\end{array}$ \\
\hline $\begin{array}{l}\text { Argumentos a favor de } \\
\text { la existencia de un solo } \\
\text { gobernante en un mismo } \\
\text { principado. }\end{array}$ & Libro III, II, cap. 3 & Parte I \\
\hline $\begin{array}{l}\text { Argumentos a favor de la } \\
\text { existencia de varios go- } \\
\text { bernantes en un mismo } \\
\text { principado. }\end{array}$ & Libro III, cap. & Libro III, II, cap. 4 & Parte II \\
\cline { 1 - 1 } $\begin{array}{l}\text { Sobre el heredamiento } \\
\text { del principado. }\end{array}$ & Libro III, II, cap. 5 & Parte III \\
\cline { 3 - 4 } & & &
\end{tabular}

De manera esquemática podemos extraer algunas conclusiones de interés relacionadas, de algún modo, con la administración en el ámbito local.

- Entre los razonamientos para defender la existencia de una sola autoridad política, Arévalo defiende que el hecho de que dos personas reinen al mismo tiempo es la señal principal de la perdición y del final del tal reino ${ }^{80}$ [I:5], pues significa el desconcierto [I:7] y la desaparición de las garantías de seguridad ciudadana [I:8-9], como confirma la experiencia histórica [I:15]. Además, dos poderes coactivos en un mismo territorio supone una contradicción desde el punto de vista del Derecho [I:16]; debe existir únicamente un gobernante como solo hay un Dios rigiendo el universo [I:6], un corazón en el cuerpo humano [I:10], un pater familias en el hogar [I:11], un general en el campo de batalla [I:12] y un único líder al frente de la Iglesia [I:13]. La res publica, sostiene Arévalo, debe regentarse a semejanza de las dignidades eclesiásticas, a cuyo modelo deben ajustarse las dignidades temporales ${ }^{81}$. En definitiva, toda comunidad es mejor y más perfectamente regida por un príncipe que por muchos ${ }^{82}$.

- En cuanto a las premisas para aprobar la división de la capacidad regidora en dos personas, busca ejemplos históricos donde esta situación no ocasiona estragos [II:15] y sostiene, además, que ello puede refrenar las ambiciones y avaricias políticas en beneficio del bien colectivo [II:7-12]. Está claro que varios ojos ven y vigilan más que uno; a su vez varias inteligencias superan en conocimientos a una sola ${ }^{83}$ [9].

- En la tercera parte, el autor ya no recopila opiniones sino que introduce ideas personales, siendo así la parte con mayor originalidad. No reprueba la convivencia de dos o más gobernadores dotados con competencias supremas siempre y cuando colaboren para anteponer el bien común [III:1], siendo este sistema, incluso, beneficioso en algunos casos concretos [III:2-5]. En último lugar, por fin, censura la primogenitura como argumento para recibir el derecho de administrar ciudades (una práctica usual en las familias de corregidores), y propone a los padres valorar las virtudes y excelencias de sus hijos para gobernar con justicia y rectitud previamente a la redacción del testamento.

\footnotetext{
${ }^{80}$ Tratado sobre la división del reino, p. 81.

${ }^{81}$ Ib., p. 86.

${ }^{82}$ Suma de la politica, p. 282.

${ }^{83}$ Tratado sobre la división del reino, p. 90.
} 
El tratadista que más insiste en las virtudes morales de los regidores y más argumentos expone para defender su designación por méritos propios es el conquense Diego de Valera (1412-1488). A diferencia del resto de autores a los que se ha hecho mención, no pertenece a la nobleza rica y poderosa del reino, sino que es un consejero de Juan II, Enrique IV e Isabel I, en todo momento alejado de aspiraciones e intrigas políticas, cuya reputación se debe a su rica formación intelectual. Es, en nuestra opinión, el compositor que mejor desvela el espíritu humanista de su tiempo; prueba de ello es el éxito que conoce en todas las cortes europeas que visita y la pluralidad de temas de su exuberante y provechosa bibliografia. Su presencia en Francia, Italia y Alemania al servicio de príncipes le permite conocer y manejar numerosas fuentes que importa a Castilla, como la Historia Teutónica, la crónica de Rodolfo de Sajonia, el Arbre de batailles de Honoré Bouvet o De dignitatibus de Bartolo de Sassoferrato, siendo el principal promotor de sus ideas en los reinos peninsulares; además emplea ágilmente opiniones de autores tan diversos como Aristóteles, Cicerón, Salustio, Séneca, Luciano, San Agustín, San Ambrosio, Juan Crisóstomo, San Gregorio, Vegecio, Boecio, Pedro Lombardo, Santo Tomás, Egidio, Dante o Boccaccio. Sus amplios conocimientos son la premisa por la que tanto reyes como aristócratas acuden a él en busca de asesoramiento e instrucciones precisas ${ }^{84}$.

Con objeto de apoyar las ideas de Bartolo y de responder a las críticas que le dedica Juan Rodríguez del Padrón en Cadira de honor $(1440)^{85}$ compone para Juan II Espejo de verdadera nobleza (1441-1444) ${ }^{86}$, un repaso en once títulos sobre las funciones y responsabilidades nobiliarias, los tipos existentes, cómo acceder a ella y los motivos por los que se puede perder. Además de la "nobleza teológica" y "natural", explica Valera, existe la "política", aquella que posee como misión gobernar el mundo; los requisitos que argumentan su existencia son el linaje, la riqueza, el servicio militar y la honorabilidad. De todos ellos, la sangre es el menos relevante porque no prueba ni devoción ni eficacia, por lo que los monarcas deben negarse a otorgar privilegios políticos por cuestiones linajudas y hacerlo solamente por recompensa a lealtades y actos sobresalientes (...nobles son llamados en dos maneras, ó por linage ó por bondat: et como quier que linage es noble cosa, la bondat pasa e vence... $)^{87}$. La postura de Valera y Bartolo no es nueva; ya en el siglo XII, Andreas Capellanus recita en su De amore: No fue tu nacimiento ni tu sangre lo que te concedió la nobleza, sino que tu singular virtud y el conjunto de tus costumbres te enriquecieron con la más digna de las noblezas ${ }^{88}$. Al final del tratado, Valera propone cuatro razones para retirar la honra nobiliaria a villanos e imprudentes y señala, además, que en el caso concreto

${ }^{84}$ Algunas aproximaciones destacadas sobre la figura de Diego de Valera son las de M. PEnNA: Prosistas castellanos..., pp. XCIX-CXXXVI; L. De Torre: "Mosén Diego de Valera: su vida y obras", Boletín de la Real Academia de la Historia, 64, 1914, 50-83, 133-168, 249-276 y 365-412; o las de J. De Mata CARRIAzo y ARroquia en el estudio preliminar a su edición de la Crónica de los Reyes Católicos, Madrid, 1927, pp. I-CLIV. Mucho más recientemente, un estado de la cuestión crítico y analítico en la segunda parte de la obra de J.D. Rodríguez-Velasco: El debate sobre la caballería en el siglo XV. La tratadística caballeresca en su marco europeo, Salamanca, 1996.

85 Vid. ed. C. Hernández Alonso: Juan Rodríguez del Padrón: obras completas, Madrid, 1982, 259-306.

${ }^{86}$ Vid. ed. M. Penna: Prosistas castellanos..., 89-116.

${ }^{87}$ Partida II, título IX, ley 6; vid. también Espejo de verdadera nobleza, p. 92.

${ }^{88}$ Tomado de M. KeEn: La caballería, Barcelona, 1986, p. 210. 
de los caballeros judíos, el hecho de que se conviertan al Cristianismo es la mayor prueba de su nobleza teológica. No debe olvidarse que sus orígenes familiares son hebraicos, por lo que le interesa defender la posibilidad de gozar del privilegio noble sin necesidad de descender de una alta alcurnia ${ }^{89}$. Dos décadas después, Per Afán de Ribera y Guzmán escribe Definición de nobleza (ca. 1474) ${ }^{90}$ y Fernán Mexía Nobiliario vero $(1477)^{91}$ para refutar a Valera y defender los convencionalismos tradicionales (... fidalguia o nobleza [...] es virtud antigua propagada de los progenitores, acompañada de riqueza... $)^{92}$.

El resto de tratados valerianos a los que haremos mención expone las cualidades técnicas y morales de la nobleza regidora. Dedicado a Juan Pacheco, Marqués de Villena, el Cirimonial de príncipes y caballeros $(1455-1460)^{93}$ enumera brevemente las virtudes aristotélicas aplicadas a la labor ministerial y resuelve las dudas al respecto de la jerarquía interna de la nobleza (marqueses, condes y duques), polemizando así con Juan de Mena, que en su Tratado sobre el título de duque $(1445)^{94}$ defiende al Duque de Medina Sidonia Juan de Guzmán ideas contrarias a la suya; la personalidad del buen gobernador vuelve a tratarse sucintamente en el Breviloquio de virtudes $(1461)^{95}$, destinado al Conde de Benavente y Señor de Villalón y Mayorga, Rodrigo Pimentel. También para el polémico Pacheco escribe el Tratado de Providencia contra fortuna (1462-1467) ${ }^{96}$, una reflexión sobre la buena y la mala fortuna a partir de las conductas adecuadas y reprobables del ser humano ${ }^{97}$. Por último, en el Doctrinal de príncipes (1476) ${ }^{98}$ resume a Fernando el Católico, nuevamente, los deberes elementales y las actitudes éticas canónicas de la aristocracia regidora: devoción, sentido de la responsabilidad, compromiso social, justicia, amor hacia los súbditos y otras cualidades más que serán enumeradas más abajo, en el apartado correspondiente ${ }^{99}$.

89 Vid. Espejo de verdadera nobleza, pp. 101-105.

${ }^{90}$ Vid. ed. M. Ambrosio SÁnchez: "La Definición de nobleza de un nuevo Per Afán y otras obritas”, en A. Menéndez Collera y V. Roncero López (Coords.): “Nunca fue pena mayor". Estudios de Literatura española en homenaje a Brian Dutton, Cuenca, 1996, 589-604, concretamente 600-604.

91 Vid. ed. Madrid, 1974.

92 Definición de nobleza, p. 601.

93 Vid. ed. M. Penna: Prosistas castellanos..., 161-168.

94 Vid. ed. L. VASVAri FainBerg: Tratado sobre el título de duque, Londres, 1976.

95 Vid. ed. M. Penna: Prosistas castellanos..., 147-154.

96 Vid. ibidem, 141-146.

${ }^{97}$ Las posibilidades de estos tratados para la educación de la nobleza con atribuciones de gobierno, a través de la figura de Juan Pacheco, lo estudio en mi artículo "El epistolario de Diego de Valera: consejos y consuelos para el Marqués de Villena (ca. 1445-1465)", Territorio, Sociedad y Poder, 6, 2011, 155-174, al cual remito para completar el análisis ofrecido.

98 Vid. ed. M. Penna: Prosistas castellanos..., 173-202.

99 Los horizontes políticos de la obra de Diego de Valera ha sido objeto de algunos estudios. El más reciente es el de S. Scandellari: "Mosén Diego de Valera y los consejos a los príncipes", Res publica. Revista de la Historia y del presente de los conceptos políticos, 18, 2007, 141-162. Otros más antiguos son los de M. Penna: "El Príncipe según Diego de Valera y el Príncipe según Maquiavelo", Revista de estudios politicos, 84, 1955, 121-138, que compara las ideas de ambos autores; o E. Toda Oliva: "Doctrinal político de Mosén Diego de Valera", Revista de estudios políticos, 52, 1950, 165-174, dedicado a la concepción teórica de la nobleza y su configuración en el órganon social. 
En la misma ciudad en la que nace Diego de Valera lo hace también el monje agustino Juan de Alarcón (finales del siglo XIV-mediados del XV); los datos sobre su vida son escasos, de hecho sólo se puede contrastar su presencia académica en Italia, su labor como consejero en la corte de Juan II de Castilla y su amistad con Álvaro de Luna; al privado dedica, de hecho, el Libro del regimiento de los señores (1420), un manual de instrucción política desde perspectiva religiosa cuyo propósito es concienciarle de la necesidad de potenciar valores como la discreción, la prudencia y la fortaleza para que pueda gozar de una larga trayectoria como regidor ${ }^{100}$. La obra se compone de seis partes divididas en diez capítulos; en las tres primeras repasa cuestiones teóricas sobre el gobierno providencial (Teología política) y en las tres restantes se detiene en los errores más frecuentes de los gobernantes (política práctica). De manera más específica, en el libro I interrelaciona el regimiento de los príncipes y nobles con la predestinación, en el II explica que todos los dirigentes ostentan su cargo por deseo divino, inclusive los malvados, y en III los exhorta a que se encomienden en oración rogando sabiduría en sus tareas. Esta exposición no es una mera síntesis del pensamiento teocrático de San Agustín pues, si bien defiende la voluntad de Dios en el designio universal (...Dios rige e gobierna el mundo...), reconoce la libertad absoluta que conocen los políticos (...los regimientos que a los príncipes encomendó lo dexa en sus manos...), hecho por el que llega a justificar el derrocamiento de los villanos e incluso el tiranicidio ${ }^{101}$. En el libro IV resume los abusos más frecuentes entre los regidores, en el $\mathrm{V}$ les invita a arrepentirse para poder gozar de la ventura celestial y en el VI enumera sus obligaciones básicas.

Otros miembros de la orden agustina que escriben sobre lecciones morales para regidores son Lope Fernández de Minaya y Martín Alonso de Córdoba. Minaya compone en dos libros Espejo del alma. El primero, dividido en tres partes, está dedicado a los pecados mundanos: concupiscencia, avaricia y soberbia (título I); mentira, temor a la muerte y olvido a Dios (título II); y a los mandamientos del Antiguo Testamento (título III). El segundo, mucho más largo (cuarenta y dos capítulos), propone consejos virtuosos para evitar tentaciones carnales ${ }^{102}$. Esta temática es similar a la segunda parte del Compendio de la fortuna (1440-1453) del profesor de Teología en Salamanca Martín Alonso de Córdoba, también destinado a exhortar a Álvaro de Luna sobre los riesgos de su polémica actitud como valido real ${ }^{103}$.

Entre los siglos XIV y XV se escriben otros muchos tratados de contenido moral destinados a un público lector amplio, no expresamente a dirigentes políticos, que contienen las mismas enseñanzas sobre los mandamientos, los pecados y las virtudes. Algunos notorios son el Rimado de palacio de Pero López de Ayala (1385-1403), que denuncia los vicios de la nobleza cortesana de la época de Enrique III; el Libro de las consolaciones de la vida humana de Pedro de Luna (1414), organizado en quince capítulos que pretenden servir de apoyo ante tribulaciones y tristezas; El Corbacho o

100 Vid. ed. B. Diferman: “¿Edición de una obra de Juan de Alarcón?”, Anuario jurídico escurialense, 2, 1961, 669-776; vid. al respecto la dedicatoria y epílogo de la obra, pp. 675 y 773.

${ }^{101}$ Vid. ibidem, I, introducción, p. 677.

102 Vid. ed. F. RuBio: Prosistas castellanos del siglo XV, II, B.A.E., tomo CLXXI, 219-267.

${ }^{103}$ Vid. ed. ibidem, 5-63. La primera parte del tratado no incluye cuestiones de gobierno sino que expone las ideas clásicas sobre la Fortuna y el hado, y su relación con el designio providencial. 
Reprobación del amor mundano de Alfonso Martínez de Toledo (1438), fuertemente influenciado por la obra de Boccaccio; o Coplas contra los pecados mortales de Juan de Mena (mediados del siglo XV). Sobre la amistad verdadera versan De las maneras del amor de don Juan Manuel (primera mitad del siglo XIV) y Tractado de la amiçiçia de Herrán Núñez (finales del siglo XV); mientras que el anónimo Libro de los gatos (finales del siglo XIV) y el Libro de los enxemplos por $A B C$ de Clemente Sánchez Vercial recogen refranes y moralejas sobre temas éticos diversos $(1420)^{104}$.

El último autor que reseñamos es Alonso de Cartagena (1384-1456), ya que su Doctrinal de los caballeros (ca. 1435-1445) no introduce ninguna novedad al tema, sino que transcribe literalmente pasajes sobre instrucciones políticas extraídas de Las Partidas y el Ordenamiento de la Banda ${ }^{105}$. El autor conoce una importancia de primer orden como uno de los tratadistas más influyentes de la época; es hijo del famoso rabino converso Pablo de Burgos, profesor de Teología en Salamanca, embajador de Castilla en el extranjero y compositor de un sinfín de escritos sobre educación moral, religiosa, crónicas y traducciones. Su fama a nivel internacional se debe a su asistencia al Concilio de Basilea (1432), donde elogia a los reyes castellanos sobre los ingleses y escandinavos ${ }^{106}$, y estrecha amistades con otros humanistas como Bruni y Pier Candido Decembrio, con quienes comparte correspondencia e ideas sobre la caballería ${ }^{107}$.

El Conde de Castro y de Denia, Diego Gómez de Sandoval, es el destinatario de la compilación de leyes que integran el Doctrinal. El libro I, dividido en nueve títulos, es el más interesante al presentar los deberes y derechos de la nobleza a partir del título XXI de la Segunda Partida. El libro II repasa en cinco capítulos las funciones defensivas de la caballería, y el libro III expone las normas sobre torneos y desafíos en seis apartados. El libro IV, por último, clasifica en nueve títulos los defectos a denostar y virtudes a ensalzar tanto en los señores como en los vasallos. Cartagena, a diferencia de Valera, no pretende innovar sino recopilar doctrina ya existente para ilustrar a la nobleza sobre sus cometidos en un tiempo en el que esta ha abandonado sus labores bélicas y aspira a afianzarse política y económicamente; como explican J.M. Viña Liste y L. Fernández Gallardo, ello supone una tensión entre la mentalidad

${ }^{104}$ Con un fin selectivo, de todo este listado de obras se hace uso de las siguientes para completar las exposiciones sobre el gobernante modélico en la tercera parte de este artículo: Libro de las consolaciones de la vida humana (vid. ed. P. DE GAYANGos: Escritores en prosa..., 561-602), Reprobación del amor mundano (vid. ed. Madrid, 1982), y Libro de los enxemplos por ABC (vid. ed. P. DE GaYAngos: Escritores en prosa..., 447-542).

105 Vid. ed. J. Viña Liste: Doctrinal de los cavalleros, Santiago de Compostela, 1995.

${ }^{106}$ Sobre estos encuentros vid. mi estudio "La ideología goticista en los prehumanistas castellanos, Alonso de Cartagena y Rodrigo Sánchez de Arévalo: sus consideraciones sobre la unidad hispano-visigoda y el reino astur-leonés", Territorio, sociedad y poder, 5, 2010, 123-145.

${ }^{107}$ Una aproximación a la vida y obra de Alonso de Cartagena en las monografías generales de L. FernáNDEZ Gallardo: Alonso de Cartagena (1385-1456): una biografia política en la Castilla del siglo XV, Valladolid, 2002; L. Serrano: Pablo García de Santa María y Alonso de Cartagena. Obispos de Burgos, gobernantes, diplomáticos y escritores, Madrid, 1942; y F. CANTERA Burgos: Alvar García de Santa María y su familia de conversos. Historia de la judería de Burgos y de sus conversos más egregios, Madrid, 1952; reeditada en Burgos, 2007. A estos títulos se debe añadir también las recensiones que aportan M. MARTínez AÑIBARro: Intento de diccionario biográfico y bibliográfico de autores de la provincia de Burgos, Madrid, 1889; y M. PENNA: Prosistas castellanos..., pp. XXXVII-LXX. 
medieval tradicional y la nueva realidad humanista ${ }^{108}$. Otros autores del siglo XV que también elaboran sus recopilaciones de leyes para gobernantes, siempre acudiendo a las mismas fuentes y sin aportaciones de ningún tipo, son Alfonso Fernández de Madrigal (De optima política, 1437), Pedro de Chinchilla (Exortaçión o ynformación de buena e sana doctrina, 1467), Alonso Díaz de Montalvo (Compilación de las leyes del reino, 1484) y Alonso Ramírez Villaescusa (Espejo de corregidores y jueces, ca. 1493).

\section{EL RETRATO IDEAL DE LA NOBLEZA GUBERNAMENTAL: ASPEC- TOS TEÓRICOS}

Los oficios de la nobleza regidora, pese a su compleja organización interna ${ }^{109}$, pueden agruparse en dos grandes conjuntos, los puramente administrativos (procuradores, consejeros, notarios, jueces, abogados, pesquisidores...) y los vinculados al servicio de la casa del rey o señor (médicos, despenseros, coperos, mensajeros, porteros...) ) $^{110}$. Nuestro interés reside en el primero de ellos, donde se integran los regidores, consejeros y jueces del ámbito urbano.

\subsection{EL ESPEJO DE REGIDOR}

La lectura comparativa de los tratados presentados más arriba permite concretar la caracterización básica del buen gobernante en el pensamiento bajomedieval ${ }^{111}$ (... todo rey o príncipe o monarca debe mucho ser ordenado y compuesto de virtudes...

108 Vid. el estudio preliminar de la edición de J.M. Viña Liste, pp. LX y ss.; y L. Fernández Gallardo: "Alonso de Cartagena y el debate sobre la caballería en la Castilla del siglo XV", Espacio, Tiempo y Forma. Serie III: Historia Medieval, 26, 2013, 77-118.

109 Para una catalogación de las magistraturas centrales y municipales del funcionariado medieval vid. J.M. García Marín: El oficio público en Castilla durante la Baja Edad Media, Madrid, 1987; sobre sus competencias y deberes morales vid. especialmente el capítulo tercero: "Los derechos, obligaciones y prohibiciones del oficial público", pp. 239 y ss. Como complemento, vid. la ponencia de G. MarTínez DíEz: "Los oficiales públicos de Las Partidas a los Reyes Católicos”, en VV.AA.: Actas del II Symposium de Historia de la Administración, Madrid, 1971, 121-137.

110 De manera más concreta, don Juan Manuel (Libro de los estados, pp. 338-341) integra en el primer grupo a los adelantados, merinos, alcaldes, alguaciles y mayordomos, y en el segundo a los médicos, criadores, tesoreros, coperos, zanqueros, reposteros, porteros, mensajeros, cocineros... subrayando especialmente las funciones del despensero, el que ha de comprar et de recabdar todas las viandas que son mester para la casa del señor, es decir, quien reparte y administra los recursos del hogar, inclusive los sueldos y los dineros. Ramón Llull (Libre de l'ordre de cavalleria, II, 7 y 8) es mucho más sucinto al recordar tan solo a los procuradores, vegueres y bailes. Por su parte, Egidio Romano (Glosa castellana..., pp. 630 y ss.; y 649 y ss.) se detiene ampliamente en describir las virtudes que deben reunir todos estos: buena apariencia, modales refinados, afabilidad, cortesía, alegría, mesura, lealtad, prudencia...

111 Vid. Libre de l'ordre de cavalleria, II (las perfecciones del caballero son las mismas que las presentes en el ideario de gobernador) y VI (sobre las virtudes morales generales); Libro de los estados, pp. 327 y ss.; Glosa castellana..., p. 793 y s.; y 822 y s.; Suma de la politica, pp. 285-287; Exhortación de la paz, pp. 82 y ss.; Espejo de verdadera nobleza, pp. 105 y ss.; Breviloquio de virtudes, pp. 147 y ss.; Cirimonial de príncipes, pp. 161 y ss.; y Doctrinal de príncipes, pp. 174 y ss. 
${ }^{112}$. Su primer requisito básico es ser devoto cristiano (...el gobernante debe ser estudioso de la ley de Dios... $)^{113}$. Juan de Alarcón recuerda a los regidores los beneficios celestiales que conocerán si cumplen los Mandamientos, así como los tormentos que sufrirán los que los desatienden [I:9-10]; recomienda, por el bien de su alma, la oración y el estado permanente en comunión con Dios [III:3] (...debe omme demandar a Dios ayuda, saber e discreçion para rregir asi mesmo et a otros, ca fuerte e dificil cosa es al omme rregir a otro omme... $)^{114}$. Para el conquense, pues, la piedad es la cualidad más valorada en el político [VI:8].

El segundo atributo elemental es la competitividad y responsabilidad en los cometidos. Ello sólo es posible si posee una formación académica de calidad, goza de vocación de servicio público y dispone de los recursos necesarios para ejercer de manera adecuada sus tareas. La principal es, como ya se ha adelantado, garantizar el bien común y la paz entre los ciudadanos, especialmente entre los ricos homes, propensos a enfrentarse en bandos políticos.

Aunque es necesario que conserve su halo de superioridad para asegurar la estabilidad del gobierno, el regidor debe procurar demostrar amor y lealtad hacia el pueblo en pro de un sentimiento correspondido, pues como explica Eiximenis, cuando el regente siente fidelidad y lealtad entre aquellos entre los cuales habita, entonces el corazón se le endurece para hacer virtuosamente y sin miedo todo lo que pertenece a su oficio ${ }^{115}$. Así, han de ofrecer su amistad y protección a las instituciones eclesiásticas, a las familias aristocráticas más influyentes, a los burgueses que ostentan el poder económico (...los mercaderes son vida de la tierra donde están, y son el tesoro de la cosa pública, y son comida de los pobres, y son brazo de todo buen negocio, de todos aferes perfección... $)^{116}$ y a los sabios e intelectuales de la ciudad, potenciando así no sólo el desarrollo económico e institucional de la ciudad sino también los programas culturales y los centros de enseñanza. Explica Egidio que el gobernante no debe menospreciar a ninguno de sus súbditos, pues ha de extender sus cuidados a los extranjeros, enfermos, pobres y demás desamparados, demostrando de este modo amor misericordioso ${ }^{117}$; por el contrario, debe perseguir todos los oficios corruptivos o que provocan mal, es decir, la nigromancia, quiromancia, juegos de azar o de lucha, alcahueterías... ${ }^{118}$ También es su responsabilidad velar por el mantenimiento de las instalaciones urbanas (edificios, templos, mercados, fortalezas, plazas, huertas...) y hacer frente a posibles contingencias como hambrunas, desastres, accidentes o guerras, de acuerdo con los patrones especificados en el modelo de ciudad ideal diseñado por Arévalo en su Suma de la politica.

112 Suma de la politica, p. 283.

113 Libro del regimiento de los señores, III, 5, p. 724.

114 Ib., III, 3, p. 721.

115 Regiment de la cosa publica, p. 90. De modo similar, Diego de Valera, en 1461, escribe al nuevo Conde de Benavente don Rodrigo Pimentel recomendándole que entre todas las cossas, procurad ser mas amado que temido; Breviloquio de virtudes, p. 150.

116 Regiment de la cosa publica, p. 112; la exposición sobre los mercaderes en pp. 111-118.

117 Vid. Libro del regimiento de los señores, VI, 9, p. 767.

118 Regiment de la cosa publica, p. 105. 
En cuanto a sus bondades personales, el gobernador debe rechazar los pecados capitales y abrazar las virtudes de la moral cristiana. Son valoradas positivamente cualidades como la humildad, la templanza, la prudencia, la fortaleza, la paciencia (la paciencia es mucho de alabar, et mas en los principes que han de gobernar) ${ }^{119}$, la apariencia física, la amabilidad, la alegría (el principe non debe triste enviar, a cualquier que algo le viene demandar $)^{120}$, la compasión, la ausencia de deseos de crueldad y venganza... ${ }^{121}$

"[El gobernante] debe ser decorado y doctado de las virtudes siguientes. Ca debe ser justo, inocente, amigable, piadoso, gracioso, concorde, rigoroso quando cumple, umano, verdadero, prudente, bien acordable, inteligente, proveido, circunspecto, enseñable, clemente, modesto, fuerte, magnámino, liberal, perfecto, constante, mando e umilde".

Cuando la autoridad pertinente no cumple estas indicaciones se convierte en un tirano, pervirtiéndose así el sistema social ${ }^{122}$. El tirano no sigue la voluntad de Dios ni responde a las demandas colectivas, sino que emplea su autoridad para lograr su propio beneficio o el de sus partidarios ${ }^{123}$. Egidio repasa algunos indicios que, en oposición a los del buen gobernante, desvelan la existencia de un líder tiránico; estos son la ausencia de prácticas piadosas, la apatía hacia la responsabilidad, el egoísmo y despotismo en la toma de decisiones, la participación en las intrigas políticas, la opresión y ataque hacia ciudadanos honorables, la ausencia de iniciativas culturales y reparo personal al ejercicio intelectual... ${ }^{124}$ Eiximenis añade más rasgos: el desfallecimiento de la conciencia, la poca virtud, la poca fortaleza y el poco amor a la comunidad, y ser afeminado y sin bondad ninguna, y ser blando, y frío, y tibio en toda cosa de bien ${ }^{125}$. Por su parte, Juan de Alarcón argumenta que, si el tirano no cesa en su maldad, es lícito derrocarle, pues su gobierno no se corresponde con el designio providencial y su destino es el castigo eterno [V].

Para evitar estas situaciones y procurar el correcto cumplimiento de los deberes políticos se recomienda la no perpetuación de los cargos, sino retirarse tras varios años de ejercitación. Ello pretende sanear el sistema gubernamental y ofrecer la oportunidad de inserción a los nuevos titulados (los regidores y juezes no deven ser perpetuados en los oficios [...] porque los officiales que supiesen que han de ser perpetuos

119 Libro de los enxemplos, enx. 276 (Patientia in principibus est laudanda), p. 514; otro refrán similar en el enx. 231 (Patientia in principibus maxima virtus est) Paciencia en los príncipes es grand virtud, e para el anima a todos es grand salud, p. 515.

${ }^{120} \mathrm{Ib}$., enx. 308 (Princeps non debet quemquam remitere tristem), p. 521.

${ }^{121}$ Suma de la politica, p. 285; textos similares en la Glosa castellana..., Castigos y documentos, pp. 189 y ss. (cuáles cosas deben los reys desear é cuales aborrescer); y el Libro del regimiento de los señores, VI, 10, p. 771.

${ }^{122}$ La explicación aristotélica de las formas de gobierno en Glosa castellana ..., p. 761 y s.

${ }^{123}$ Vid. Partida II, título I, ley 10.

124 Vid. Glosa castellana... pp. 801-814. Alarcón enumera los diez pecados más comunes de los gobenantes convertidos en tiranos en su Libro del regimiento de los señores, IV, pp. 731 y ss. Por otro lado, la muerte de Boecio por orden de Teodorico lleva a Clemente Sánchez Vercial a considerar al rey ostrogodo el paradigma de tirano cultural; vid. su Libro de los enxemplos, enx. 43, p. 457.

${ }^{125}$ Regiment de la cosa publica, p. 87. 
en los tales oficios cometerían muchas injurias y farian oprensiones y agravios a sus vecinos $)^{126}$.

Arévalo y Valera evocan, como modelos a seguir por sus facultades políticas, a diferentes líderes de la Antigüedad y Edad Media sobradamente conocidos por los destinatarios de sus tratados. Subrayan las iniciativas legislativas de Licurgo y Solón, la humildad de Filipo de Macedonia, la valentía de Alejandro Magno, la sabiduría de Mitrídates, la capacidad de mando de Julio César, la clemencia de Augusto, la paciencia de Vespasiano, la templanza de Trajano, la piedad de Constantino, la eficiencia de Leovigildo, la devoción de Recaredo y Alfonso I, la veneración religiosa de Alfonso II, el liderazgo de Carlomagno, el interés por la Historia de Alfonso III, la prudencia del conde Fernán González, la franqueza de Fernando I, la erudición de Alfonso X, la afección por el Derecho de Sancho IV y Alfonso XI, la intelectualidad del marqués Íñigo López de Mendoza, la disposición de Alfonso $\mathrm{V}$ a recibir consejos, el apego hacia la literatura del emperador Segismundo de Hungría, la justicia del duque Alberto de Hungría... Son anti espejos, entre otros muchos y por diferentes motivos, el rey Herodes, Calígula, Nerón, Teodorico, Witiza, el conde don Julián, Mauregato o Pedro I ${ }^{127}$.

\subsection{LAS VIRTUDES DEL CONSEJERO}

Los regidores deben escuchar los dictámenes de sus asesores antes de tomar una decisión de importancia; ignorar sus opiniones es una muestra más de ofuscación tiránica (...el consejo del que mucho sabe, al tiempo menester mucho valle) ${ }^{128}$, pues contribuyen, como expertos, a valorar las necesidades ciudadanas, predecir situaciones y solucionar problemas. En Las Partidas se define en qué consiste el consejo (... bon entendimiento que home toma sobre las cosas dubdosas porque non pueda caer en yerro...) y su labor (...los consejeros son sabidores del consejar por arte ó por uso...) para enumerar a continuación los atributos morales que deben poseer quienes lo ofrecen (...deben seer homes entendudos et de buena fama, et sin sospecha et $\sin$ mala codicia... $)^{129}$ :

"Este consejo debe tomar con homes que hayan en sí dos cosas; la primera que sean sus amigos, la segunda que sean bien entendidos et de buen seso: ca si tales non fuesen, poderle hie ende avenir grant peligro, porque nunca los que á home desaman le pueden bien aconsejar nin lealmente [...] otrosi Moguer el consejero fuese mucho su amigo,

126 Suma de política, p. 292

127 Vid. Libro de los enxemplos, enx. 174, p. 489 (sobre Licurgo y las leyes justas); y Doctrinal de príncipes, pp. 175 y ss.

${ }^{128}$ Libro de los enxemplos, enx. 6 (Consilium prudentis in necesitate maxima multum prodest), p. 448.

129 Las frases entre paréntesis corresponden a la Partida III, título XXI, leyes 1 y 2; el párrafo, dedicado al Consejo Real (Partida II, título IX, ley 5), es perfectamente aplicable a las propiedades y responsabilidades intrínsecas del consejero del regidor urbano. Egidio ofrece otra definición de "consejo" en su obra: es sabiduría de pensar, según razón, lo mejor que puede ser en todas las obras de los ommes; vid. Glosa castellana..., p. 833. El autor transcribe esta sentencia de la obra de Aristóteles (Éticas, IV). Otra definición en la misma obra, esta vez inspirada en la que ofrece Cicerón (Rethoricae, I): consejo es razón pesada sobre el apetito de lo que el omme quiere facer o no facer. 
si non hobiese en sí buen seso ó buen entendimiento, non le sabrie bien aconsejar nin derechamente, nin tener en poridat las cosas quel dixese".

Nuestros tratados insisten mucho sobre los cuidados a tener en cuenta al elegir a los consejeros; Egidio Romano y Sánchez de Arévalo son quienes mejor caracterizan su instrucción y sus cualidades morales, siendo sus fuentes directas Aristóteles, Cicerón, Séneca y Valerio Máximo ${ }^{130}$ :

"No solamente conviene al buen político escoger con diligencia las personas de los consejos, más aun deve con industria examinar y discutir sus consejos [...] deve con su propio ingenio y entendimiento deliberar y considerar cuáles consegeros son más provados y más ciertos y sanos".

Los consejeros deben estar facultados para su oficio, lo que significa que han de poseer conocimientos probados en Artes y Derecho, así como acumular años de experiencia laboral; sólo así estarán capacitados para opinar sobre asuntos tan dispares como la gestión de recursos, promulgación de leyes o asuntos de paz. También deben poseer buena fama y costumbres; son de valorar virtudes como la devoción espiritual, la fidelidad, la honestidad, la templanza, la prudencia... ${ }^{131}$

"Los consejeros deven ser discretos y prudentes y constantes en la fee y justicia, onestos e de buenas costumbres, otrosí sotiles y providentes, verdaderos y no lisongeros".

"Para que la tal cibdad o reino sea bien regido o gobernado, es necesario que [los gobernantes] tengan sabios y discretos consejeros, ábiles y expertos y prudentes, mirando más a la prudencia política que no a la militar o béllica [...] quesean personas de gran prudencia y experiencia".

De igual modo, son de denostar aquellos candidatos que, como sostiene Juan de Alarcón, presentan indicios de ser sospechosos, traidores, desleales, mentirosos, egoístas, avariciosos [III:10] y muy especialmente aduladores [III:6] por no ofrecer credibilidad para ejercer su oficio ${ }^{132}$. A este respecto, Egidio advierte que el consejero dos cosas ha de haver, que no sea manifiesto ni lisonjero ${ }^{133}$; por su parte, Eiximenis recuerda el castigo bíblico para los regidores que se dejan arrastrar por la locura de sus malos asesores ${ }^{134}$. El refranista Clemente Sánchez Vercial recoge dos dichos rimados sobre esta problemática: El consejo engañoso, siempre es dañoso; y Del que mal consejo diere, nescio es quien lo creyere ${ }^{135}$.

130 Vid. Glosa castellana..., pp. 828 y ss.; y Suma de la politica, pp. 288-292. El párrafo en Suma de la politica, p. 290; vid. correspondencia con Glosa castellana..., p. 828.

131 Suma de la politica, pp. 284 y 288.

132 Vid. Libro del regimiento de los señores, III, 3 y 10, pp. 725 y 729; Glosa castellana..., pp. 839-844; y Regiment de la cosa publica, p. 91.

133 Glosa castellana..., p. 837.

134 Regiment de la cosa publica, p. 94.

135 Libro de los enxemplos, enx. 7 (Consilia dolosa minime sunt credenda), p. 449; y enx. 5 (Consilium pravum non est accipiendum), p. 448. 
Teniendo en cuenta las escrupulosas exigencias, se recomienda un número reducido de consejeros (...uno sea tu consejero de mil... $)^{136}$ que incluya tanto prelados de la Iglesia ${ }^{137}$ como caballeros y burgueses cuyo nivel de rentas no sea excesivamente elevado para que sean conscientes de las demandas reales ${ }^{138}$. De igual modo deben gozar de un sueldo sustancial y de la confianza de sus superiores, que deben mostrarse agradecidos de su labor y no recriminarles posibles errores ${ }^{139}$.

\subsection{CARACTERIZACIÓN BÁSICA DEL JUEZ MUNICIPAL}

Los jueces ordinarios son los encargados de velar por el cumplimiento de la legalidad existente en las villas ${ }^{140}$. En la Tercera Partida se define su ejercicio (...los judgadores que facen sus oficios como deben han nombre con derecho jueces, que quiere tanto decir como homes bonos que son puestos para mandar et facer derecho... $)^{141}$; sólo pueden ser designados por la realeza o sus vicarios regionales, siendo requisito básico jurar lealtad a la Corona al tomar posesión del cargo ${ }^{142}$. La Séptima Partida amplía considerablemente este contenido al especificar las sanciones que el juez debe imponer ante delitos como el falseo de pruebas en el juicio, estafa, traición, blasfemia, herejía, hurto, adulterio, violación, homicidio..., así como las posibles condenas: multas, azotes, confiscación de bienes, prisión temporal, arresto vitalicio, destierro, pena de muerte... También enumera y clasifica los distintos tipos de juez: permanente, delegado, metropolitano, árbitro, de comisión, de bienes confiscados, de puertos, de mestas y cañadas, de naipes, pedáneo... Egidio es mucho más sucinto al diferenciar sólo entre los ordinarios (los que examinan pleitos comunes) y los especiales (para las apelaciones); sobre los segundos, son menester en cada cibdad alcaldes mayores e

136 Glosa castellana..., p. 841; sentencia a su vez tomada de Aristóteles.

137 Vid. Libro del regimiento de los señores, III, 8, p. 727.

138 Suma de la politica, p. 292;

139 Vid. Regiment de la cosa publica, p. 96; y Glosa castellana..., pp. 839 y ss.

140 Las definiciones de "juez" son bastantes simples en los tratados de Llull (Libre de l'ordre de cavalleria, II, 9), don Juan Manuel (Libro de los estados, pp. 339 y ss.), Egidio (Glosa castellana ..., p. 629) y Alonso de Cartagena (Doctrinal de los cavalleros, p. 47) ya que, sus exposiciones, no se centran en el ámbito de la justicia urbana sino en instituciones mayores como la Audiencia, la Cancillería Mayor, las Merindades y los Adelantamientos. Es preciso distinguir la "justicia" como función pública de la "justicia" como virtud moral. Diego de Valera (Breviloquio de virtudes, p. 148 y s.; Exhortación de la paz, p. 80 y s.; y Doctrinal de príncipes, p. 194 y s.) compone su teoría al respecto a partir de la lectura de Aristóteles, Macrobio, Salustio, Séneca, Cicerón y San Agustín: La justicia tiene siete partes: religión, piedad, inocencia, amistança, reverencia, concordia, misericordia. El conquense considera la justicia un ábito o condición por el qual somos obradores de justas caussas (Exhortación de la paz) y diferencia dos tipos, la legal o escrita (aquella por la cual el ciudadano está sometido por Derecho) y la particular (aquella justicia que de si mesmo cada uno fase; vid. Breviloquio); esta segunda puede ser distributiva (aquella que conviene al rey o príncipe, duque o governador de la tierra, en el dar o repartir de los oficios, dignidades e rentas y en el rescebir de qualesquier cossas que le pertenezcan; vid. Exhortación de la paz) o conmutativa (aquella que se exerce en las contrataciones que unos con otros fasemos; vid. Breviloquio). Egidio también ofrece estas mismas definiciones en Glosa castellana..., p. 108.

${ }^{141}$ Partida III, título IV, ley 1.

142 Vid. Partida III, título IV, leyes 2 y 6. 
sabios, porque si los pleitos mal juzgados fueren en la abdiencia común, los alcaldes mayores los enderescen... ${ }^{143}$

Otros oficios vinculados al procedimiento judicial son los abogados, que actúan como portavoces de los demandantes o demandados en los pleitos; los alguaciles, que inspeccionan sobre el cumplimiento de las sanciones dictaminadas por la justicia; los pesquisidores, que actúan para que los oficiales cumplan con sus responsabilidades; o los notarios, que dan fe de los actos extrajudiciales ${ }^{144}$. Todos ellos deben responder a un mismo espejo de virtudes que, en líneas generales, es análogo al presentado anteriormente para los regidores y consejeros (formación académica, devoción cristiana, vocación, rectitud, sabiduría, buena fama, magnificencia, paciencia, honradez, prudencia.... $)^{145}$.

"[Deben] primeramente seer de buen linage para haber vergüenza de non errar; et luego cabo desto deben haber buen entendimiento para entender aina lo que razonaren ante ellos; et deben seer apuestos et sesudos para saberlo departir et judgar derechamente [...] Otrosi deben seer firmes de manera que non se desvien del derecho nin de la verdat, nin fagan contra ello por ninguna cosa que les podiese ende venir de bien ni de mal. Et sobre todo han de ser muy leales de manera que sepan guardar todas estas cosas sobredichas, et señaladamente que amen al rey, et guarden su señorio et todas sus cosas".

"[...] Que sean leales et de buena fama, et sin mala cobdicia, et que hayan sabiduría para judgar lo pleitos derechamente por su saber ó por uso de luengo tiempo, et que sean mansos et de buena palabra á los que vinieren en juicio ante ellos, et sobre todo que teman á Dios et al que los hi pone; ca si á Dios temieren guardarse han de facer pecado, et habrán en sí piedat et justicia; et si al señor hobieren miedo recelarse han de facer cosa por do les venga mal dél viniéndoles emiente como tienen su logar para judgar derecho".

El Ordenamiento de Alcalá determina la edad de veinte años (veinticinco según Las Partidas) para que un individuo pueda ejercer como juez; debe, además, estar en posesión de un título expedido por un studium generale con la firma del rey ${ }^{146}$. Francesc Eiximenis y Sánchez de Arévalo concretan otros requisitos elementales y exclusivos de los jueces ${ }^{147}$ :

Su horario laboral, por ejemplo, es de lunes a viernes desde primera hora de la mañana al mediodía. Los veredictos adoptados deben ajustarse a la estricta legalidad sin influencia de ningún tipo de condicionante pasional (parentesco, amistad o enemistad con los procesados). Su único deseo ha de ser ajusticiar con piedad y sabiduría en el

143 Glosa castellana..., p. 749.

${ }^{144}$ Sobre estos oficios vid. Partida III, título IV-VIII (jueces, personeros, abogados, emplazamientos, asentamientos) y XVII-XXXI (pesquisidores, escribanos, notarios, selladores, consejeros).

145 Partida II, título IX, ley 18; y Partida III, título IV, ley 4. Vid. asimismo Ordenamiento de Alcalá, título XXXII, leyes 42 y 43 .

146 Vid. Partida III, título IV, leyes 5-7; y Ordenamiento de Alcalá, título XXXII, ley 44.

147 Vid. Regiment de la cosa publica, p. 83 y s.; Suma de la politica, pp. 292 y ss.; y Glosa castellana..., pp. 749 y ss.; y 850 y ss., especialmente pp. 860-871. Todas las cualidades señaladas se mantienen inalteradas durante toda la Edad Moderna, como se puede comprobar en tratados de finales del XVIII como el de L. GUARDIOLA Y SÁEz: El corregidor perfecto y juez dotado de las cualidades necesarias, Madrid, 1796. 
deseo de proteger el bien común, por lo que las sanciones impuestas deben ser mesuradas y acordes a la pena del delito cometido ${ }^{148}$; como reza el refrán, El juez con saña non puede bien juzgar, nin las partes oir nil derecho examinar ${ }^{149}$.

Nuestros tratadistas insisten en que, pese al poder de algunos nobles y burgueses, el juez debe aplicar la ley a todos los ciudadanos por igual, sin distinción alguna de estado o nivel de riqueza, si bien reconocen la atención especial que merecen los más indefensos, como los labradores, huérfanos, peregrinos y mendigos. Independientemente de estos factores, todos los individuos poseen el mismo derecho a ser defendidos por medio de abogados de oficio ${ }^{150}$. Por último, el magistrado debe informar de sus resoluciones por escrito; para ello se apoya en un cuerpo de escribanos públicos que asiste a las vistas judiciales tomando nota de todo cuanto sucede. El canon ético de estos amanuenses se ajusta al de los notarios y demás oficios públicos ${ }^{151}$.

Si los regidores, sus consejeros y los jueces responden al modelo expuesto, los ciudadanos vivirán en una ciudad próspera demostrando felicidad a la par que una actitud sumisa, reverente, obediente y leal hacia los poderes superiores ${ }^{152}$.

\section{EN SUMA}

La literatura didáctica sobre el buen gobierno se desarrolla de manera paralela a la prosperidad que conocen las ciudades europeas a lo largo de los siglos XIII-XV. Sus líderes políticos, preocupados por llevar a cabo sus quehaceres de la manera más adecuada posible, encargan a intelectuales de prestigio tratados formativos que resuman las leyes existentes sobre gobierno local e incluyan consejos personales para la buena gerencia.

Estos testimonios se definen por la dependencia absoluta hacia las fuentes clásicas (Aristóteles), cristianas (San Agustín) y contemporáneas del humanismo europeo (Latini, Egidio, Bruni, Sassoferrato). El hecho de que los tratados estudiados expongan prácticamente las mismas ideas sin apenas diferencias se debe a que sus autores comparten un mismo sistema de valores y la mentalidad propia del humanismo bajomedieval. Todos ellos coinciden al aceptar las proposiciones de los autores Clásicos, que traducen, imitan e incluso transcriben con literalidad sin introducir conceptos personales originales, preconizando así el espíritu del humanismo renacentista en una Europa donde el tráfico de ideas y convicciones es cada vez más denso.

148 Juan de Alarcón considera la misericordia el atributo más importante del juez [VI:8]; vid. Libro del regimiento de los señores, VI, 8, p. 762.

149 Libro de los enxemplos, enx. 152 (Iracundus judicii non valet causam contueri), p. 483. Otro refrán en la misma obra, Las justas leyes son de guardar, e sin mudacion siempre durar, enx. 174 (Leges justae sunt servandoe sine mutatione), p. 489.

${ }^{150}$ Vid. Suma de la politica, p. 297; y Regiment de la cosa publica, p. 89 y s.

151 Vid. Partida III, título IV, ley 7; y Glosa castellana ..., p. 749.

${ }^{152}$ Sobre las virtudes de los vasallos vid. Suma de la politica, pp. 302-209; Glosa castellana..., pp. 935954; y Castigos y documentos, pp. 106 y ss. Junto al sometimiento a los regidores destacan el servicio a Dios y la caridad hacia los semejantes. Vid. también Libre de l'ordre de cavalleria, VII; y el Libro de los estados, p. 132 . 
En lo referido a los títulos más importantes, en el siglo XIII, las versiones cristianas de las composiciones sapienciales orientales y Llull plantean tímidamente el tema de la gerencia política de las ciudades hasta que, en la segunda mitad de la centuria, Las Partidas diseñan el marco teórico sobre su legislación y Sancho IV ordena la traducción de varios manuales básicos, entre ellos, el Libre dou tresor de Latini, y el epítome de De regimine principum de Egidio que supone los Castigos y documentos. En los siglos XIV y XV el género conoce su desarrollo como género literario gracias a obras, precedidas por las de don Juan Manuel y Pero Gómez Barroso, como el Regiment de la cosa publica de Eiximenis, la Suma de la politica de Arévalo, el conjunto de trataditos de Valera o las distintas versiones glosadas de la obra de Egidio, entre las cuales destaca la de Juan García de Castrojeriz. Una importancia menor poseen las obritas de otros religiosos que, aunque escriban sobre regimiento urbano, lo hacen fruto de un pretexto de aleccionamiento religioso, no político (Minaya, Alarcón).

Los temas principales que desarrollan estas composiciones son:

1. Concepción del poder político: defensa del orden social establecido por argumento de Providencia y exposición de las funciones sociales de cada estado.

2. Pedagogía cristiana: recordatorio sobre los mandamientos, los artículos de la fe, los pecados y las promesas celestiales para los buenos gobernantes.

3. Virtudes morales básicas y responsabilidades específicas de los regidores, consejeros y jueces.

Si los tratados permiten concretar el espejo teórico de la nobleza gubernamental, las crónicas y los documentos en archivo permiten comprobar hasta qué punto se cumplen estas normas. Esta cuestión ya la abordé en otro estudio anterior, al cual remito $^{153}$.

\section{APÉNDICE. TRATADOS PARA EL ESTUDIO DE LA CIUDAD BAJOME- DIEVAL: UNA SELECCIÓN REPRESENTATIVA}

La tabla recoge, por orden cronológico, un listado de los tratados italianos e hispánicos más importantes citados a lo largo de la exposición. Pese a su influencia en nuestros autores, por cuestiones de espacio se ha omitido la obra de los clásicos grecolatinos, los Padres de la Iglesia y de la tradición oriental con las únicas excepciones de Aristóteles, Vegecio y San Agustín por ser, en todo momento, los más recurridos.

153 Vid. J. Villa Prieto: “Luces y sombras en la representación del ideal de nobleza. Los Fernández de Quiñones en las crónicas de Juan II de Castilla", en VV.AA.: Learning from the past: Methodological considerations on Studies of Antiquity and Middle Ages. Proceedings of the First Postgraduate Conference on Studies of Antiquity and Middle Ages (Barcelona, 26-28th October 2010), Barcelona, 2011, 258-267. 


\begin{tabular}{|c|c|c|}
\hline FECHA & AUTOR & Título \\
\hline S. IV a.C. & Aristóteles & Politica \\
\hline Siglo IV & Vegecio & De re militari (libro IV) \\
\hline Ca. $413-426$ & San Agustín & De civitate Dei contra paganos \\
\hline Ca. 1100 & Honorio de Autum & \begin{tabular}{|l|} 
Lucidarium \\
Tr. Lucidario
\end{tabular} \\
\hline S. XII-XIV & VV.AA. & Corpus iuris civilis \\
\hline Ca. 1220 & Guido Fava & Summa de vitiis et virtutibus \\
\hline Ca. 1222 & Anónimo & Oculus pastoralis \\
\hline $1238-1253$ & Giovanni da Viterbo & Liber de regimine civitatum \\
\hline 1245 & Orfino da Lodi & De sapientia potestatis \\
\hline 1246 & Albertano de Brescia & Liber consolationis et consilii \\
\hline Ca. 1250 & Vincent de Beauvais & Speculum doctrinale \\
\hline $1256-1265$ & Alfonso X & Las Partidas (I: I; II: II-V y IX-X; y III: IV-VIII y XXI) \\
\hline $1260-1267$ & Brunetto Latini & $\begin{array}{l}\text { Libre dou tresor (libro III) } \\
\text { Tr. Libro del tesoro }\end{array}$ \\
\hline Med. S. XIII & Sancно IV & Castigos y documentos \\
\hline 1275 & Ramón Llull & Libre de l'ordre de cavalleria \\
\hline 1275 & Ramón Llull & Doctrina pueril \\
\hline 1276 & Ramón Llull & Arbre de la ciencia \\
\hline 1280 & Egidio Romano & De regimine principum (libro III) \\
\hline 1293 & Pero Gómez Barroso & Libro del consejo e de los consejeros \\
\hline 1296 & Ramón Llull & Libre de contemplació en Déu \\
\hline Pri. S. XIV & Dante Alighieri & De monarchia \\
\hline 1324 & Marsilio de Padua & Defensor pacis \\
\hline $1326-1328$ & Don Juan Manuel & Libro del caballero et del escudero \\
\hline $1327-1332$ & Don Juan Manuel & Libro de los estados \\
\hline $1330-1335$ & Don Juan Manuel & Libro de Patronio o El conde Lucanor \\
\hline 1336 & Don Juan Manuel & Libro infinido \\
\hline 1336 & Don Juan Manuel & Libro infinido o Libro de los castigos o consejos \\
\hline Ca. 1344 & Bartolo de Sassoferrato & De nobilitate \\
\hline Ca. 1356 & Bartolo de Sassoferrato & De insigniis et armis \\
\hline Med. S. XIV & Paolo da Certaldo & Libro di buoni costumi \\
\hline 1383 & Francesc Eiximenis & Regiment de la cosa publica \\
\hline 1392 & Francesc Eiximenis & Crestià (libro XII) \\
\hline 1399 & Coluccio Salutati & De nobilitate legum \\
\hline 1400 & Coluccio Salutati & De tyranno \\
\hline 1403 & Leonardo Bruni & Historiarum florentinarum \\
\hline 1418 & Pedro de Portugal & Livro da virtuosa benfeitoria \\
\hline 1420 & Juan de Alarcón & Libro del regimiento de los señores \\
\hline
\end{tabular}




\begin{tabular}{|c|c|c|}
\hline 1422 & $\begin{array}{l}\text { Buonaccorsi de } \\
\text { Montemagno }\end{array}$ & De nobilitate \\
\hline 1422 & Leonardo Bruni & De militia \\
\hline 1430 & Arnau Stanyol & Libre del regiment dels princeps \\
\hline $1435-1445$ & Alonso de Cartagena & Doctrinal de los caballeros \\
\hline 1437 & $\begin{array}{l}\text { Alfonso Fernández de } \\
\text { Madrigal }\end{array}$ & De optima política \\
\hline Pri. S. XV & $\begin{array}{l}\text { Alfonso Fernández de } \\
\text { Madrigal }\end{array}$ & $\begin{array}{l}\text { Comentario al tratado sobre el "Regimiento de los } \\
\text { Príncipes" de Egidio Colonna }\end{array}$ \\
\hline 1438 & Duarte de Portugal & Leal conselheiro \\
\hline 1440 & $\begin{array}{l}\text { Juan Rodríguez del } \\
\text { Padrón }\end{array}$ & Cadira de honor \\
\hline $1440-1453$ & $\begin{array}{l}\text { Martín Alonso de Cór- } \\
\text { doba }\end{array}$ & Compendio de la fortuna \\
\hline $1441-1444$ & Diego de Valera & Espejo de verdadera nobleza \\
\hline 1445 & Juan de Mena & Tratado sobre el título de duque \\
\hline 1455 & $\begin{array}{l}\text { Rodrigo Sánchez de } \\
\text { Arévalo }\end{array}$ & Suma de la politica \\
\hline $1455-1460$ & Diego de Valera & Cirimonial de príncipes y caballeros \\
\hline 1461 & Diego de Valera & Breviloquio de virtudes \\
\hline $1462-1467$ & Diego de Valera & Tratado de Providencia contra fortuna \\
\hline Med. S. XV & $\begin{array}{l}\text { Lope Fernández de } \\
\text { Minaya }\end{array}$ & Espejo del alma \\
\hline 1465 & Matteo Palmieri & Della vita civile \\
\hline 1467 & Pedro de Chinchilla & Exortaçión o ynformación de buena e sana doctrina \\
\hline $1467-1468$ & $\begin{array}{l}\text { Rodrigo Sánchez de } \\
\text { Arévalo }\end{array}$ & Liber de regno dividendo \\
\hline 1468 & $\begin{array}{l}\text { Rodrigo Sánchez de } \\
\text { Arévalo }\end{array}$ & Speculum vitae humanae \\
\hline Ca. 1474 & $\begin{array}{l}\text { Per Afán de Ribera y } \\
\text { Guzmán }\end{array}$ & Definición de nobleza \\
\hline 1476 & Diego de Valera & Doctrinal de príncipes \\
\hline 1477 & Fernán Mexía & Nobiliario vero \\
\hline 1484 & Alonso Díaz de Montalvo & Compilación de las leyes del reino \\
\hline Ca. 1493 & $\begin{array}{l}\text { Alonso Ramírez Villaes- } \\
\text { cusa }\end{array}$ & Espejo de corregidores y jueces \\
\hline 1513 & Maquiavelo & Il principe \\
\hline
\end{tabular}




\section{FUENTES}

Alfonso Martínez de Toledo: El Corbacho o Reprobación del amor mundano. Ed. Madrid, 1982.

Alfonso X: Las Partidas. Ed. LóPez, Gregorio, 3 vols., Madrid, 1955. Ed. facsímil, Madrid, 1985.

Alonso de Cartagena: Doctrinal de los cavalleros. Ed. Viña Liste, José, Santiago de Compostela, 1995.

Aristóteles: Obras completas. Ed. AzcÁRate, Patricio, 4 vols., Buenos Aires, 1947.

Bartolo de Sassoferrato: Antología. Ed. 8 vols., Munich, 1846.

Clemente Sánchez Vercial: Libro de los enxemplos por ABC. Ed. Gayangos, Pascual de: Escritores en prosa anteriores al siglo XV , B.A.E., tomo LI, Madrid, 1860, 447-542.

Diego de Valera: Antología. Ed. Penna, Mario: Prosistas castellanos del siglo XV, I, B.A.E., tomo CXVI, Madrid, 1959, 55-202.

Don Juan Manuel: Antología. Ed. Gayangos, Pascual de: Escritores en prosa anteriores al siglo XV, B.A.E., tomo LI, Madrid, 1860, 234-367.

Egidio Romano: De regimine principum. Ed. Samaritanium, Hieronymun, Aalen, 1967.

Fernán Pérez de Guzmán: Crónica de Juan II (refundición de Lorenzo Galíndez de Carvajal). Ed. Rosell, Cayetano: Crónicas de los Reyes de Castilla, II, B.A.E., tomo LXVIII, Madrid, 1953, 273-695.

Ferrán MeXía: Nobiliario vero. Ed. Madrid, 1974.

Francesc Eiximenis: Regiment de la cosa pública. Ed. CALderó i CABRÉ, Albert, Barcelona, 1999.

Juan de Alarcón: Libro del regimiento de los señores. Ed. Diferman, Bonifacio: “¿Edición de una obra de Juan de Alarcón?”, Anuario jurídico escurialense, 2, 1961, 669-776.

Juan García de Castrojeriz: Del regimiento de los príncipes y señores que han de regir a los otros (Glosa a "De regimine principum" de Egidio Romano). Ed. BENEYTo PÉREZ, Juan, Madrid, 2005.

Juan Rodríguez del Padrón: Cadira de honor. Ed. Hernández Alonso, César: Obras completas, Madrid, 1982, 259-306.

Leonardo Bruni: Opere letterarie e politiche. Ed. Viti, Paolo, Turín, 1996.

Lope Fernández de Minaya: Espejo del alma. Ed. Rubio, Fernando: Prosistas castellanos del siglo XV, II, B.A.E., tomo CLXXI, Madrid, 1964, 219-267.

Marsilio de Padua: El defensor de la paz. Ed. Martínez Gómez, Luis, Madrid, 1989.

Martín Alonso de Córdoba: Compendio de la Fortuna. Ed. Rubio, Fernando: Prosistas castellanos del siglo XV, II, B.A.E., tomo CLXXI, Madrid, 1964, 5-63. 
Pedro de Luna: Libro de las consolaciones de la vida humana. Ed. Gayangos, Pascual de: Escritores en prosa anteriores al siglo XV, B.A.E., tomo LI, Madrid, 1860, 561-602.

Per Afán de Ribera y Guzmán: Definición de nobleza. Ed. Ambrosio Sánchez, Manuel: "La Definición de nobleza de un nuevo Per Afán y otras obritas", en MeNÉNDEZ Collera, Ana; y Roncero López, Victoriano (Coords.): "Nunca fue pena mayor". Estudios de Literatura española en homenaje a Brian Dutton, Cuenca, 1996, 589-604, concretamente 600-604.

Pero Carrillo de Huete: Crónica del Halconero. Ed. Mata Carriazo y Arroquia, Juan de, Madrid, 1946.

Pero López de Ayala: Rimado de Palacio. Ed. Madrid, 2011.

RAMÓn Llull: Antología. Ed. Batllori, Miguel: Ramón Llull: obra escogida, Barcelona, 1981, 485-494.

Ramón Llull: Libre de contemplació en Déu. Ed. GayÀ Estelrich, Jordi, 8 vols., Palma de Mallorca, 2000.

Rodrigo Sánchez de Arévalo: Antología. Ed. Penna, Mario: Prosistas castellanos del siglo XV, I, B.A.E., tomo CXVI, Madrid, 1959, 249-341.

Rodrigo SÁnchez de Arévalo: Tratado sobre la división del reino y cuándo es lícita la primogenitura. Ed. SolóRzano Telechea, Jesús Ángel, Logroño, 2011.

Sancho IV: Castigos y documentos. Ed. Gayangos, Pascual de: Escritores en prosa anteriores al siglo XV, B.A.E., tomo LI, Madrid, 1860, 79-228.

\section{BIBLIOGRAFÍA}

Alvar Ezquerra, Carlos; y Lucía Megías, José Manuel: Diccionario filológico de Literatura Medieval española: textos y transmisión, Madrid, 2002.

AnTelo Iglesias, Antonio: "La ciudad ideal según fray Francesc Eiximenis y Rodrigo Sánchez de Arévalo", En la España medieval, 6, 1985, 19-50.

Asenjo GonzÁlez, María: "La utopía política en el ámbito urbano", en Alvira CABRER, Martín y Díaz IbÁÑEz, Jorge (Coords.): Medievo utópico. Sueños, ideales y utopias en el imaginario medieval, Madrid, 2011, 141-154.

BADIA PAmiés, Lola: Ramón Llull: vida, pensament i obra literaria, Barcelona, 1988.

Beltrán, Rafael: "El valor del consejo en los Castigos e documentos del rey don Sancho", Alvar Ezquerra, Carlos; y Lucía Megías, José Manuel (Coords.): La Literatura en la época de Sancho IV. Actas del Congreso Internacional (Alcalá de Henares, 21-24 de febrero de 1994), Alcalá de Henares, 1996, 107-120.

BERMúDEZ AzNAR, Agustín: "El asistente real en los concejos castellanos medievales", en VV.AA.: Actas del II Symposium de Historia de la Administración, Madrid, 1971, 223-251.

Bermúdez Aznar, Agustín: El corregidor en Castilla durante la Baja Edad Media, Madrid, 1970. 
Bonachía Hernando, José Antonio: "La ciudad en Las Partidas: edificaciones y apostura urbana", en Ribeiro, María do Carmo; y Sousa Melo, Arnaldo (Coords.): Evoluçâo da paisagem urbana. Transformaçâo morfológica dos tecidos históricos, Braga, 2013, 91-117.

Bonachía Hernando, José Antonio: "Obras públicas, fiscalidad y bien común en las ciudades de la Castilla bajomedieval", en Monsalvo AnTón, José María (Coord.): Sociedades urbanas y culturas políticas en la Baja Edad Media castellana, Salamanca, 2013, 17-48.

Bonachía Hernando, José Antonio: "La imagen de la ciudad en Las Partidas: edificación, seguridad y salubridad urbanas", Cuadernos de Historia de España, 85-86, 2011-2012, 115-134.

Bonachía Hernando, José Antonio: "Entre la «ciudad ideal» y la «sociedad real»: consideraciones sobre Rodrigo Sánchez de Arévalo y la Suma de la Politica, Studia Historica. Historia Medieval, 28, 2010, 23-54.

CARrasco Manchado, Ana Isabel: "Análisis de las fuentes literarias castellanas para la historia de la cultura política en la Edad Media: el ejemplo de política, políticos, politizar", en Fernández LóPez, María Concepción; SuÁrez Fernández, Mercedes; VeigA, Alexandre (Coords.): Oh Lux Iberiae. En torno a las letras en la España Medieval, Lugo, 2013, 181-201.

Castro y Calvo, José María: El arte de gobernar en las obras de don Juan Manuel, Barcelona, 1945.

Cayetano Martín, Carmen: "La ciudad medieval y el Derecho: el urbanismo en Las Partidas", Anales de Historia del Arte, 4, 1993-1994, 65-70.

CERdÁ Ruiz-Funes, Joaquín: "Jurados, iurats, en municipios españoles de la Baja Edad Media (reflexiones para una comparación)", Historia, instituciones, documentos, 14, 1987, 27-39.

Cervera Vera, Luis: Francesc Eiximenis y su sociedad urbana ideal, Madrid, 1989.

Cherubini, Giovanni: Le città europee del Medioevo, Milán, 2009.

Cruz Hernández, Miguel: El pensamiento de Ramón Llull, Valencia, 1977,

Díaz DíAz, Gonzalo: Hombres y documentos de la Filosofía española, VII, Madrid, 2003.

Díez Garretas, María Jesús: "Juan García de Castrojeriz, ¿traductor de Egidio Romano?", en Reglero de La Fuente, Carlos Manuel (Coord.): Poder y sociedad en la Baja Edad Media hispánica. Estudios en homenaje al profesor Luis Vicente Díaz Martín, I, Valladolid, 2002, 133-141.

Fernández Gallardo, Luis: "Alonso de Cartagena y el debate sobre la caballería en el siglo XV", Espacio, tiempo y forma. Serie III: Historia Medieval, 26, 2013, 77-118.

Fernández Gallardo, Luis: Alonso de Cartagena (1385-1456): una biografia política en la Castilla del siglo XV, Valladolid, 2002.

Ferrer NaVARro, Ramón: Eiximenis i la seua obra, Valencia, 2010. 
Gaibrois de Ballesteros, Mercedes: El príncipe don Juan Manuel y su condición de escritor, Madrid, 1945.

García Cue, Juan Ramón: “Teoría de la ley y de la soberanía popular en el Defensor pacis de Marsilio de Padua", Revista de estudios políticos, 43, 1985, 107-148.

GARCÍA MARÍN, José María: El oficio público en Castilla durante la Baja Edad Media, Madrid, 1987.

Gómez Moreno, Ángel: España y la Italia de los humanistas. Primeros ecos, Madrid, 1994.

GonzÁlez Alonso, Benjamín: El corregidor castellano (1348-1808), Madrid, 1970.

Guglielmi, Nilda: La ciudad medieval y sus gentes: Italia, siglos XII-XV, Buenos Aires, 1981.

HaRo CoRTÉs, Marta: La imagen del poder real a través de los compendios del siglo XIII, Londres, 1996.

HaRo CoRTés, Marta: Los compendios de castigos del siglo XIII: técnicas narrativas y contenido ético, Valencia, 1995.

LaboA, Juan María: Rodrigo Sánchez de Arévalo, alcaide de Sant'Angelo, Madrid, 1973.

LóPeZ De Goicochea Zabala, Javier: "La glosa castellana al De Regimine Principum (1280) de Egidio Romano. La reducción aristotélica", Saberes. Revista de estudios jurídicos, económicos y sociales, 1, 2003. Disponible On-line en $<\mathrm{http}$ ://www.uax. es/publicaciones/archivos/SABFUN03_007.pdf> [con acceso el 2-II-2010].

López Estrada, Francisco: "Sobre la difusión del Tesoro de Brunetto Latini en España", Gesammelte Aufsätze zur Kulturgeschichte Spaniens, 16, 1960, 137-152.

LóPEZ-AMo y MARín, Ángel: "El pensamiento político de Eiximenis en su tratado Regiment de Prínceps", Anuario de Historia del Derecho español, 17, 1946, 5-139.

Maíz CHACón, Jorge: "La argumentación filosófica del caballero medieval. El modelo e ideal luliano en el Libre del Orde de Cavaleria", Mirabilia. Revista eletrônica de História Antiga e Medieval, 5, 2005, disponible On-line en <http://www.revistamirabilia.com/nova/images/numeros/2005_05/05.pdf $>$ [con acceso el 3-X-2012].

Mancineli, Chiara: "Francesc Eiximenis y su programa pedagógico", Forma. Revista d'estudis comparatis: Art, Literatura, Pensament, 3, 2011, 101-109.

Martín, José Luis: "El tratado de caballería de Francesc Eiximenis", Norba, 16.1, 1996-2003, 295-331

MarTín, José Luis: La ciudad y el príncipe. Estudio y traducción de los textos de Francesc Eiximenis, Barcelona, 2004.

Martínez Díez, Gonzalo: "Los oficiales públicos de Las Partidas a los Reyes Católicos", en VV.AA.: Actas del II Symposium de Historia de la Administración, Madrid, 1971, 121-137.

Montero, Ana M.: "La castellanización de Li libres dou tresor de Brunetto Latino en la corte de Sancho IV (1284-1295): algunas notas sobre la recepción de la ética aristotélica", Anuario de estudios medievales, 40 (2), 2010, 937-954. 
MuRATORE, Giorgo: La ciudad renacentista: tipos y modelos a través de los tratados, Madrid, 1980.

Nogales Rincón, David: "En torno a la sabiduría en el Cuatrocientos castellano: el prólogo a la traducción castellana del De regno ad regem Cypri de Tomás de Aquino dirigida a Fernando el Católico", Memorabilia, 12, 2009-2010.

Nogales Rincón, David: "Los espejos de príncipes en Castilla (siglos XIII-XV): un modelo literario de la realeza bajomedieval", Medievalismo. Boletín de la Sociedad Española de Estudios Medievales, 16, 2006, 9-39.

Pérez de Tudela y Velasco, María Isabel: "Ideario político y orden social en Las Partidas de Alfonso X”, En la España medieval, 13, 1991, 183-200.

RodrígueZ-Velasco, Jesús D.: El debate sobre la caballería en el siglo XV. La tratadística caballeresca en su marco europeo, Salamanca, 1996.

RuBIo, Fernando: "De regimine principum de Egidio Romano en la Literatura castellana de la Edad Media", La Ciudad de Dios, 173, 1960, 32-71.

Ruzz Gómez, Francisco: "La ciudad en la obra jurídica alfonsí: el paisaje urbano y los grupos de poder", en GonZÁlez JiMÉnez, Manuel (Coord.): El mundo urbano en la Castilla del siglo XIII, I, Sevilla, 2006, 101-121.

SAnchis Guarner, Manuel: "L'ideal cavalleresc definit per Ramon Llull", Estudios lulianos, 2, 1958, 37-62.

SAntoja, Pedro: "Francesc Eiximenis y su época: finales del siglo XIV y principios del siglo XV", Azafea. Revista de Filosofia, 2, 1989, 19-35.

SCANDEllari, Simonetta: "Mosén Diego de Valera y los consejos a los príncipes", Res publica. Revista de la Historia y del presente de los conceptos políticos, 18, 2007, 141-162.

Tejada, Francisco Elías de: "Ideologia e utopia no Livro da virtuosa benfeitoria", Revista portuguesa de Filosofia, 3, 1947, 5-19.

VILA, Soledad: La ciudad de Eiximenis: un proyecto teórico de urbanismo en el siglo XIV, Valencia, 1984.

Villa Prieto, Josué: "El epistolario de Diego de Valera: consejos y consuelos para el Marqués de Villena (ca. 1445-1465)", Territorio, Sociedad y Poder, 6, 2011, 155-174.

WitTlin, Curt. J.: "Les traduccions catalanes medievals del Tresor de Brunetto Latini", en MAFFIA SCARIATI, Irene (Coord.): Indagini sulla ricezione di Brunetto Latini dal Medioevo al Rinascimento, Firenze, 2008, 167-176. 